\title{
Uniting the Arts to Stage the Nation: Le Sueur's Ossian (1804) in Napoleonic Paris
}

\author{
ANNELIES ANDRIES* (1)
}

\begin{abstract}
This article argues that the early nineteenth century was a critical period in the development of operatic aesthetics in France: fuelled by post-Revolutionary notions about theatre's importance in processes of nation-building, the Opéra sought to strengthen its reputation as the 'Académie that unites all the arts'. The intertwinement of this aesthetic and political aim are conspicuous in the production of Jean-François Le Sueur's Ossian ou les bardes (1804), loosely based on James Macpherson's Ossianic 'translations'. The work's meticulous coordination of the arts sought to bring third-century bardic society back to life and make audiences feel part of this long-forgotten, supposedly 'historical' and French, past. Thus, this article points to the Opéra's intensifying interaction with nationalism and genealogical historiography around 1800 as it sought to define its role as a national theatre. Thus, it also challenges the common scholarly notion that the Opéra's productions served primarily to aggrandise Napoleon.
\end{abstract}

Mon ombre réveillée au tumulte des armes, Sur la Gaule affranchie a vu de toutes parts La guerre et la victoire unir leurs étendards Mes ancêtres, penchés au bord de leurs nuages, D'un regard protecteur, à travers les orages, Suivant les bataillons des braves triomphants, A l'heure du péril ont cru voir leurs enfants. Ils t’admiraient surtout, fils de la Renommée, Héros libérateur d'une terre opprimée. ${ }^{1}$

(My ghost, awakened by the tumult of arms, saw war and victory unite their banners all around freed Gaul. Leaning on the edge of their clouds, my ancestors followed the battalions of the brave victors through the storms with a watchful eye. They believed they saw their children at the hour of peril. They admire you, above all, son of Fame, Liberating hero of an oppressed earth.)

* Annelies Andries, Magdalen College, University of Oxford; annelies.andries@magd.ox.ac.uk For their generous and insightful comments, I would like to thank Gundula Kreuzer, Sarah Hibberd, Rebekah Ahrendt, Sarah Waltz, Katherine Hambridge and Marco Ladd as well as the two reviewers for the Cambridge Opera Journal. I am also indebted to the Whitney and Betty MacMillan Center for International and Area Studies at Yale, which supported the archival research in its early stages. All translations are my own unless otherwise stated.

1 'Ossian à Napoléon', L'observateur des spectacles, de la littérature et des arts, 4 prairial an X (24 May 1802). 
Residing on their clouds, the legendary third-century bard, Ossian, and his ancestors admire Napoleon and his brave warriors 'liberating the earth'. Fantastical scenes like the one in this poem were common in political art in early nineteenth-century France. They were crafted to pay tribute to the political achievements of France's new ruler, Napoleon, and capitalised on his enthusiasm for James Macpherson's 'translations' of the epic poems of Ossian. ${ }^{2}$ This particular panegyric was written to applaud two of Napoleon's 1802 victories: securing peace with Britain in the Treaty of Amiens and winning the support of the Tribunat and Corps législatif in his bid to become 'Consul for life.' The Ossianic Heavens are also depicted in Anne-Louis Girodet's painting L'apothéose des héros français (1802), where an old, blind Ossian and his ancestors welcome French military heroes in the afterlife (Fig. 1). Literary scholar Tili Boon Cuillé and art historian George Levitine have argued that the symbolic content of this painting celebrated the settlement of two major conflicts in 1801: the Treaty of Lunéville, ending the hostilities with Austria, and the Concordat with Pope Pius VII, which restored the relationship between France and the Roman Catholic Church. ${ }^{4}$

In 1804, the Ossianic Heavens were presented once again to Parisian audiences in Jean-François Le Sueur's opera Ossian ou les bardes. Whereas Ossian had mostly been depicted as an old, blind man reciting the bards' epic histories, the opera, in contrast, shows him as a youthful warrior liberating his fellow bards and fiancée Rosmala from their Scandinavian oppressors. During this endeavour, Ossian finds himself imprisoned in Act IV dreaming of being welcomed in the bardic afterlife. The Opéra's artists had spared no effort in making this the most astonishing scene possible. Le Sueur had requested twelve harps - in addition to a full orchestra - to accompany the songs and dances of the celestial bards. ${ }^{5}$ On stage, a large number of forces personified Ossian's ancestors: forty-five singers, sixty-six dancers and several supernumeraries. ${ }^{6}$ They were majestically clad in white tunics and fur cloaks, with swords and shields at their sides, and 'silver crowns of immortality' on their

2 On Napoleon's fascination with Macpherson's Ossianic poetry, see Frank George Healy, The Literary Culture of Napoleon (Geneva, 1959), 120-1 and 127-32.

3 The Treaty of Amiens was signed on 25 March 1802, marking the beginning of a year of peace in Europe. Napoleon exploited this achievement to make his successful bid to become 'Consul for life', for which he acquired the support of the Tribunat and Corps législatif in May 1802. These results were ratified by a public plebiscite on 2 August 1802. See Philip G. Dwyer, The Citizen Emperor: Napoleon in Power, 1799-1815 (London, 2013), 101-2.

4 George Levitine, 'L'aigle épouvanté de l'“Ossian" de Girodet et l'aigle effrayé du mausolée de Turenne', Gazette des beaux-arts (1974), 319-23; and Tili Boon Cuillé, 'From Myth to Religion in Ossian's France', in The Super-Enlightenment: Daring to Know too Much, ed. Dan Edelstein (Oxford, 2010), 251-2.

5 See Jean-François Le Sueur, Ossian ou les bardes (Paris, [1805]), 541. Le Sueur could secure only eight harps for the premiere. See a letter from Joseph-Balthasar Bonet de Treiches to Jean-Baptiste-Charles Legendre de Luçay, 8 messidor an XII (27 June 1804). F-Pan AJ ${ }^{13} 90$.

6 See the cast list in [Paul Dercy and Jacques-Marie Deschamps], Ossian ou les bardes (Paris, 1804), [iii, v-vi]. 


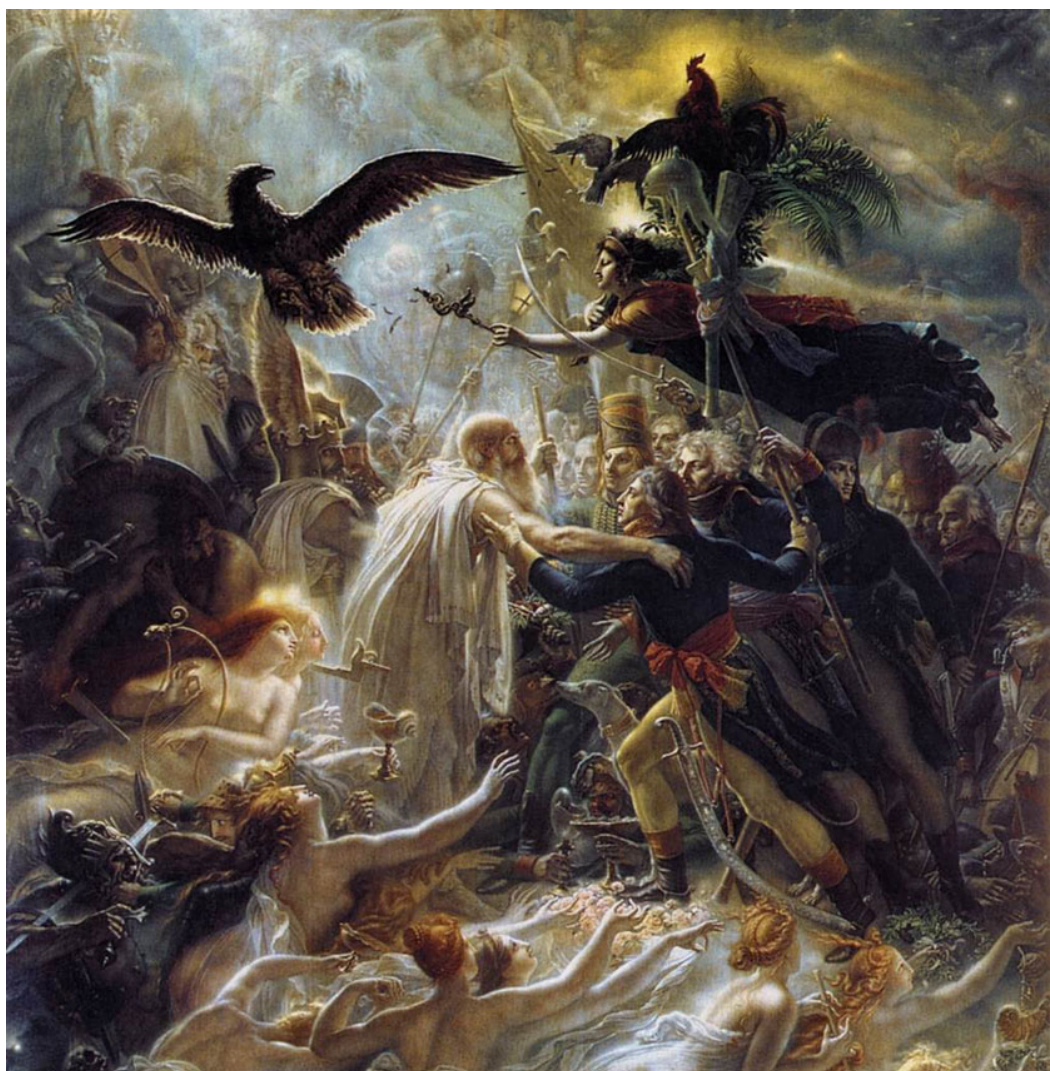

Fig. 1: Anne-Louis Girodet de Roucy-Troison, L'apothéose des héroes français morts pour la Patrie pendant la guerre de Liberté (1802) (Musée nationale de Malmaison et Bois-Préau).

heads. ${ }^{7}$ The sets were larger and more complex than any created in recent memory, consisting of numerous movable cloud panels that were lifted one by one to reveal a three-tiered, thirty-eight-foot-high celestial palace. ${ }^{8}$ An impressive visual effect was produced towards the end of the scene: as in a vision, Ossian's tomb suddenly appeared to the side of the palace and was surrounded by Rosmala and her companions lamenting the hero's passing with dramatic gestures. ${ }^{9}$ The score specified that the tomb was to become visible 'behind a light and transparent gauze, which softens and distances the objects' to emphasise its dreamlike character. ${ }^{10}$ Critics waxed lyrical about the entire scene. The Journal de commerce described it as 'an absolute fairy tale',

7 [Jean-Simon Berthélémy], 'Neuf plaques de costumes'. F-Pbmo D216 1 (24-32). These costumes are also described in the score, see Le Sueur, Ossian ou les bardes, 388.

8 Since no set designs survive, information is taken from the detailed descriptions and quotations of the Opéra's set designer and machinist, Pierre Boullet. [Pierre Boullet], 'Programme pour l'opéra d'Ossian ou les bardes' and 'Ce que couterons les décorations des bardes'. F-Pan $\mathrm{AJ}^{13} 90$.

9 Le Sueur, Ossian on les bardes, 407-12.

10 Le Sueur, Ossian ou les bardes, 409. 
and the literary journal Mercure de France called it 'a ravishing novelty'. 11 The Gazette nationale even boasted that 'scenic illusion and theatrical magic cannot go any further than in this dream scene'. 12

Like other contemporary depictions of the bardic Heavens, Ossian's dream seems emblematic of government-sanctioned art in the Napoleonic era. Using spectacular artistic means, it celebrated the ruler's literary taste. And, as musicologist David Charlton and Tili Boon Cuillé have pointed out, it contains elements that praise his reconciliation with the Catholic Church in $1801 .^{13}$ Simultaneously, it conveyed a clear patriotic message: the dream praised the military valour of young men who die defending their country. Ossian's opening night, moreover, marked an important political occasion: it was the first work to premiere at the Opéra after Napoleon had become 'Emperor of the French', and the government had provided generous financial funds so that the production's splendour would properly celebrate this occasion. ${ }^{14}$ At the second performance, Napoleon publicly endorsed the opera by calling Le Sueur into his box and later rewarded him with a golden snuffbox and a knight's medal of the Légion d'honneur. ${ }^{15}$

Because of the momentous political significance of Ossian's premiere, the opera is often trivialised in music scholarship as little more than a pièce de circonstance. In larger histories of French opera by scholars such as Vincent Giroud and Winton Dean, Ossian is characterised as emblematic of a 'new' operatic style befitting the First Empire: a work full of flamboyant visual effects that openly glorifies the sovereign. ${ }^{16}$ Such a characterisation is further supported in the two detailed studies of operatic life in early nineteenth-century Paris that concentrate on Napoleon's (and by extension the government's) control over and use of the Opéra: Rüdiger Hillmer's Die Napoleonische Theaterpolitik (1999) and David Chaillou's Napoléon à l'Opéra (2004). ${ }^{17}$ Because of this characterisation, opera production under Napoleon is typically considered a conservative return to ancien régime aesthetics and inconsequential to larger nineteenth-century artistic and especially musical developments.

11 See Journal de commerce and Mercure de France, 23 messidor an XII (14 July 1804).

2 See Gazette nationale on Le moniteur universel, 23 messidor an XII (14 July 1804). A similar comment was made the next day in the Petites Affiches, 24 messidor an XII (15 July 1804).

13 Cuillé, 'From Myth to Religion in Ossian's France', 251-2, and David Charlton, 'Ossian, Le Sueur and Opera', Studies in Music 11 (1977), 47-8. Reprinted in David Charlton, French Opera, 1730_ 1830: Meaning and Media (Aldershot, 2000).

14 From March 1804 onward, the government became strongly involved in the production of Ossian, requesting among other things that no sets or costumes from older productions were to be reused, but that all should be made new. F-Pan $\mathrm{AJ}^{13} 90$.

15 The meeting of Napoleon with Le Sueur is mentioned in La correspondence des amateurs musiciens, 30 messidor an XII (21 July 1804).

16 Vincent Giroud, French Opera, A Short History (New Haven, 2010), 105-11; and Winton Dean, 'French Opera', in The Age of Beethoven, 1790-1830, ed. Gerald Abraham (London, 1982), 72-3 and 83-5. A similar image of opera under Napoleon is given in Evan Baker, From the Score to the Stage: An Illustrated History of Continental Opera Production and Staging (Chicago, 2013), 121-7.

17 Rüdiger Hillmer, Die Napoleonische Theaterpolitik: Geschäftstheater in Paris (1799-1815) (Cologne, 1999); and David Chaillou, Napoléon et l'Opéra: la politique sur la scène, 1810-1815 ([Paris], 2004). 
Nonetheless, a handful of musicologists have been eager to establish the importance of Ossian in developments towards French grand opéra and Richard Wagner's music dramas. Manuela Jahrmärker, for example, has argued that the treatment of the bards in this opera prefigures that of historical societies in grand opéra: the bards are an integral rather than auxiliary part of the action and are represented as a fully developed society with its own traditions, belief systems and political struggles. ${ }^{18}$ According to David Charlton and Jean Mongrédien, the opera's esoteric symbolism, religious ritual and new mythological universe are suggestive of Wagner's Ring des Nibelungen and Parsifal. ${ }^{19}$ Ossian has also been studied in relation to the origins of the Gesamtkunstwerk. The detailed coordination between music and visual elements prescribed in the printed score led Aubrey Garlington to proclaim that in Ossian Le Sueur achieved a 'synthesis of the arts', by fusing 'harmony, stage action, machinery, local colour, instrumentation, and above all melody ... into a coherent, cohesive unity, in which no one genre will dominate'. ${ }^{20}$ While inviting us to look more broadly at Ossian's position in nineteenth-century opera history - a welcome move after dismissals of the opera as mere propaganda - these discussions have often sidelined the relation between the artists' aesthetic choices and the opera's political content. Mongrédien even seemed keen to dissociate the work from its political baggage by emphasising that neither Napoleon nor his political achievements could have inspired Le Sueur's opera since it had already been conceived in 1795 as an opéra comique for the Théâtre Feydeau. ${ }^{21}$

This article shows that the political situation in France around 1800 was in fact an important catalyst for the aesthetic choices made at the Opéra and in Jean-François Le Sueur's Ossian. In particular, I argue that processes of post-Revolutionary nationbuilding were the foundation for the Opéra's endeavours to restore its political and artistic prestige as 'an Académie that unites all the arts'. Macpherson's poems offered a particularly potent subject to buttress these goals: as I will discuss, the Ossianic bards had become important to the nation's identity in the 1790s when they were adopted as long-forgotten forefathers of the French. Bringing this 'historical' bardic society to life through a meticulous coordination of the operatic arts was believed to make audience members feel as if part of the 'historical' world on stage. Thus, the production could elicit experiences of historical continuity and unity with a longforgotten French past - experiences that, according to historian Benedict Anderson, were vital to the development of nineteenth-century nationalisms. ${ }^{22}$ Ossian

18 Manuela Jahrmärker, Ossian: Eine Figur und eine Idee des europäischen Musiktheaters um 1800 (Cologne, 1993), 87-8. A similar claim was made in Sieghart Döhring and Sabine Henze-Döhring, Oper und Musikedrama im 19. Jabrbundert. Handbuch der musikalischen Gattungen 13 (Laaber, 1997), 11; and Matthias Brzoska, 'Ossian ou les bardes', in Pipers Ensylklopädie des Musiktheaters, Band 3 (Munich, 1989), 481-3.

19 Jean Mongrédien, 'Ossian à l'Opéra (1804)', in Regard sur l'Opéra: du 'Ballet Comique de la Reine' à l'Opéra de Péking (Paris, 1976), 100; and Charlton, 'Ossian, Le Sueur and Opera', 47-8.

20 Aubrey S. Garlington Jr., 'Lesueur, Ossian, and a "Synthesis of the Arts", Symposium: A Quarterly Journal in Modern Literatures 18 (1964), 352-6.

21 Mongrédien, 'Ossian à l'Opéra (1804)', 89.

22 Benedict Anderson, Imagined Communities: Reflections on the Origin and Spread of Nationalism, rev. and ext. edn (London, 2006), 191-210. 
demonstrates that concerns about operatic aesthetics in early nineteenth-century France went beyond local praise for one of Napoleon's triumphs; instead, they were inextricably intertwined with broad political questions about the role of the arts in processes of French identity formation.

\section{'An académie that unites all the arts'}

The decade following the French Revolution turned out to be one of the most challenging periods for the Opéra. While ballet enjoyed a surge in popularity and artistic efflorescence, the audiences' enthusiasm for opera plummeted. ${ }^{23}$ New works failed to win favour, and instead the tragédies byriques of Christoph Willibald von Gluck and his contemporaries were endlessly repeated, creating a wistful nostalgia for the 'golden age' of the 1770s and 1780s. ${ }^{24}$ Meanwhile, competition with other theatres increased as Paris saw an explosion in theatrical activity after the freedom unleashed by the Le Chapelier laws of $1791 .^{25}$ This competition came especially from Parisian opéra comique theatres, which successfully attracted large audiences; the Thêatre Feydeau in particular rivalled the Opéra with its spectacular productions praised for their 'union of distinguished artists' and the 'cooperation of all their forces to create grand works'. ${ }^{26}$

The critics' praise for the 'union' and 'cooperation' at the Feydeau may well have been perceived as a genuine threat to the Opéra, whose advocates boasted about its distinctive artistic identity as 'an Académie that unites all the arts, a spectacle unique in Europe'. ${ }^{27}$ Creating an institution that would combine poetry, music, dance and

23 On the popularity of ballet, see Jean Mongrédien, French Music from the Enlightenment to Romanticism 1789-1830 (Portland, OR, 1996), 73; and Ivor Guest, Ballet under Napoleon (Alton, 2001), 1-3.

24 Between 1789 and 1799, only eleven new full-length tragic operas were premiered; but three were successfully performed during more than one season. Close to 80 per cent of the repertoire consisted of pre-Revolutionary operas. Performance data has been collected from the Journal de l'Opéra ([Paris: Bibliothèque-Musée de l'Opéra, 19..-1981]), digitised on Gallica (Bibliothèque nationale de France).

25 The Le Chapelier law stated that royal or government permission was no longer a prerequisite to opening a new theatre, a measure that quickly led to an unseen proliferation of small theatres in Paris. On its effect on the Opéra, see Mark Darlow, Staging the French Revolution, Cultural Politics and the Paris Opéra 1789-1794 (Oxford, 2012), 107-9 and 118-24.

26 Almanach des spectacles, an III (1794-5), 198; and Almanach des spectacles, an VIII (1798-9), 88.

27 This description of the Opéra's unique artistic identity was prominent in the writings of Denis-Pierre-Jean Papillon de la Ferté (1727-94), administrator of the Menus-Plaisirs du Roi. It crops up in pre-Revolutionary notices to champion more generous royal patronage, as well as in the $1790 \mathrm{~s}$, in appeals to the Revolutionary governments. He often argued that subsidising expensive but unique spectacles would be rewarding, for it would attract foreigners and thus make the Parisian economy thrive. When writing to the king, he attributes this rationale to Louis XIV's minister of Finance, Jean-Baptiste Colbert. See [Denis-Pierre-Jean Papillon de la Ferté] 'Notice' (c.1785), f. 1r (F-Pan, $\mathrm{O}^{1}$ 617.17); 'Mémoire' (after 1785), f. 1r (F-Pan, $\mathrm{O}^{1}$ 617.36); and 'Conclusion' (c.1790), f. $1 \mathrm{r}$ (F-Pan, $\mathrm{O}^{1}$ 617.46). The latter is a manuscript draft for the print from which the above quote is taken: [Denis-Pierre-Jean Papillon de la Ferté], Réflexions sur l'Opéra et sa conservation [s.d., s.l.], 1. 
painting had served to legitimise the Opéra's foundation in 1669 as an academy for perfecting French arts. ${ }^{28}$ Yet, sociologist Victoria Johnson has argued that this feature was highlighted again in the 1790s, when the Opéra was in danger of being demolished as a royalist symbol; now, it was used to prove that the institution was not just an extension of the court, but an emblem of French artistic prowess that added to the political prestige of the nation. ${ }^{29}$ As a consequence, the Opéra's management sought ways to strengthen this artistic identity, aspiring not just to perfect each art, but also to facilitate an unparalleled coordination between them.

This aspiration lay at the root of some of the extensive reforms at the Opéra in 1798 , which focused on creating a more collaborative artistic environment. ${ }^{30}$ The directors even proposed to pay dancers as much as singers, hoping they would better 'unite' their forces in performance (this rule was short lived, though, because of the singers' outrage that their wages had historically been much higher). ${ }^{31}$ A more effective measure was the creation of the maitre de la scène, whose task was to secure a greater congruity between the performers and their gestures. According to the statutes, the maître de la scène would indicate the movements for all singers, and consult with the chorus master, ballet master and principal singers to ensure that all movements followed the 'intentions of the poem' - this also suggests that the goal was to establish a uniform interpretation guided by the libretto text and translated into performers' bodily movements. ${ }^{32}$

The establishment of a jury de l'art was another successful accomplishment of the 1798 reforms. This jury was to decide which libretti should be recommended for performance to circumvent an administrator's incompetence or personal favouritism. ${ }^{33}$ This procedure was not entirely new. During the early 1780s, judging libretti had been one of the multiple duties of the Opéra's committee, a group of eight artist employees of the Opera who theoretically governed the theatre until about $1789 .{ }^{34}$ Yet, as musicologist Solveig Serre notes, the committee did not include a literary specialist, which led them at times to invite an outside person, Jean-Baptiste-Antoine Suard, to assist with libretto evaluations. ${ }^{35}$ Yet some authors were able to bypass this system

28 See Victoria Johnson, Backstage at the Revolution: How the Royal Paris Opera Survived the End of the Old Regime (Chicago, 2008), 108-10.

29 Johnson, Backstage at the Revolution, 78-82.

30 Joseph-Louis Francoeur, Simon-Nicholas Denesle and Réné-Gaston Baco de la Chapelle], Compte rendu au Directoire exécutif, par les C.ns Francoeur, Denesle et Baco sur le théatre de la République des Arts, à l'administration duquel ils ont été appelés le 29 germinal an 6 (Paris, an IV [1798]).

31 [Francoeur, Denesle and Baco de la Chapelle], Compte rendu au Directoire exécutif, 14-15. The proposal is included the Opéra's statutes: 'Règlement du Théâtre de la République et des Arts', 29 brumaire an VII (19 October 1798), 8v. F-Pan AJ ${ }^{13} 72$.

32 See [Francoeur, Denesle and Baco de la Chapelle], Compte rendu au Directoire exécutif, 13; and 'Règlement du Théâtre de la République et des Arts', 29 brumaire an VII (19 October 1798), 2v.

33 [Francoeur, Denesle and Baco de la Chapelle], Compte rendu au Directoire exécutif, 15.

34 Solveig Serre, L'Opéra de Paris, 1749-1790: politique culturelle au temps des Lumières (Paris, 2011), 63-72.

35 The committee included the general director, assistant director, head of music, head of the orchestra, two heads of the ballet, a painter, the Académie's secretary and the oldest among its principal actors. Serre, L’Opéra de Paris, 69 and 220-1. 
and the committees' (sometimes flawed) procedures and decisions drew widespread complaints. ${ }^{36}$ The jury de l'art proposed in 1798 had the advantage of being created specifically to evaluate a libretto as the basis for a work that united the arts. Moreover, the envisioned composition of the jury was remarkably versatile and inclusive:

For the economic aspect, it will include administrators; for the mise en scène, the two designers of costumes and sets; for the performance, the three directors of singing, dance and the orchestra; for judgements about the poetry, two men of letters; for the structure of the work, two composers; and for recording the minutes of the meeting, a librettist as permanent secretary who also has a vote. ${ }^{37}$

The jury that eventually emerged in the October 1798 statutes only encompassed 'one administrator, two men of letters, two composers, two directors (of singing and the orchestra), and two artists of the theatre (de facto male principal singers)'. ${ }^{38}$ Nevertheless, its changing configuration over the following years indicates an ongoing interest in a more holistic approach to opera, where each art is considered integral to the work. From 1801 onwards, the accountant, the ballet master, the head machinist and the head of set design were all invited to attend in an advisory capacity. ${ }^{39}$ And, in 1804, a proposal to give the maître de la scène and the ballet master voting rights was considered by the Opéra's management. ${ }^{40}$

This more holistic attention to the work can be seen as resulting from what French theatre scholar Pierre Frantz has called the 'tableau aesthetic', which developed out of a more general growth in the appreciation of theatre's visual aspects during the eighteenth century. ${ }^{41}$ Denis Diderot was one of its standard bearers; he compared theatre to a series of animated paintings, and declared that the visual, bodily performance of actors was equally important as - if not more powerful than - the text in arousing or 'moving' the audience emotionally. ${ }^{42}$ This aesthetic was perhaps most conspicuously on display at the boulevard theatres, in their ever more popular melodramas and pantomime pieces, as well as in the grand-scale, immersive Revolutionary festivals of the 1790s. ${ }^{43}$ Still, the Opéra also partook in this development. From the mideighteenth century onwards, both the theatre's management and the critics started

36 Serre, L'Opéra de Paris, 222-3.

37 [Francoeur, Denesle and Baco de la Chapelle], Compte rendu au Directoire exécutif, 16.

38 'Règlement du Théâtre de la République et des Arts', 29 brumaire an VII (19 October 1798), 6v.

39 'Règlement du Théâtre de la République et des Arts', 19 ventôse an IX (10 March 1801), 7v. F-Pan $\mathrm{AJ}^{13} 72$.

40 'Projet de Règlements pour l'Académie impériale de musique dressé par M. Bonet directeur', 23 r. F-Pan $\mathrm{AJ}^{13} 53$.

41 Pierre Frantz, L'esthétique du tableaux dans le théâtre du XVIIIe siècle (Paris, 1998).

42 Erika Fischer-Lichte, 'Der Körper als Zeichen und als Erfahrung: Über die Wirkung von Theateraufführungen', in Theater im Kulturwandel des 18. Jahrhunderts, Inszenierung und Wabrnehmung von Körper-Musik-Sprache, ed. Erika Fischer-Lichte and Jörg Schönert (Göttingen, 1999), 59-60.

43 On the popularity of pantomime and melodrama, see Katherine Hambridge and Jonathan Hicks, eds., The Melodramatic Moment: Music and Theatrical Culture, 1790-1820 (Chicago, 2018), 3-6. The Revolutionary festivals have been extensively discussed in Mona Ozouf, Festivals and the French Revolution, trans. Alan Sheridan (Cambridge, MA, 1988). 
to publish articles acclaiming the efforts of the choreographer, set designer and machinist. $^{44}$

Another intrinsic quality of the tableau aesthetic was its heightened attention to the representation of historical subject matters and their couleur locale. According to Frantz, this attention was part of a historiographical trend that understood societies as products of their temporal and spatial environments and thus had implications for theatrical verisimilitude. ${ }^{45}$ While the term couleur locale originated in seventeenthcentury pictorial criticism, it was used by critics from the 1780 s onwards to evaluate whether a plot's specific time and place were satisfactorily communicated through sets, costumes, libretto and music. ${ }^{46}$ As I will discuss later, detailed attention to couleur locale became an integral part of Le Sueur's theories on uniting the arts in Ossian. Yet first it is necessary to establish the importance of the Ossianic bards to the Opera's mission of proving its utility as a national theatre.

In addition to buttressing its artistic identity as the theatre that unites all the arts, the Opéra's function as a national rather than just royal theatre also hinged on the educational value of the plots. Educating audiences had always been one of theatre's (and thus opera's) many functions, but after the Revolution, governments actively encouraged theatres to stage pieces capable of instilling Republican values, as scholars such as literary historian Mark Darlow have noted. ${ }^{47}$ Darlow has argued that this had a profound effect on the repertoire of the Opéra, which during the Reign of Terror (1792-4) became conspicuously patriotic, often by bringing recent revolutionary events onto the stage. ${ }^{48}$ After the fall of Robespierre in 1794, patriotic pieces did not vanish from the Opéra's stage, but they more often appeared in an allegorical or historical guise, for instance in plots set in ancient Greece or Rome - places that had long been part of France's genealogical histories. ${ }^{49}$ 
Still, Romans and Greeks were not the only people that cropped up in national genealogies; by the 1790s, they had been joined by the Ossianic bards. However, the French interest in Macpherson's translations of the supposedly 'primitive' thirdcentury bardic epics predates their incorporation in genealogical narratives; already in the 1760s, they had been enthusiastically welcomed in France as writers were looking for an 'antidote to the artificiality of eighteenth-century French poetry'. ${ }^{50}$ Part of the poems' success was attributable to the fact that Ossianic culture fitted well with contemporary interests in the 'noble savage à la Rousseau' and literary sentimentalism. ${ }^{51}$ Then, towards the end of the century, these poems started to play a more specific cultural role in what literary scholar Deirdre Dawson has described as a search for 'a distinctive linguistic and cultural ancestor that was indigenous to the soil of France,. ${ }^{52}$ These ancestors were the Gauls, who had supposedly wandered out to regions such as Scotland after the Roman invasions. ${ }^{53}$ As a result, Macpherson's Ossianic translations were hailed as windows onto primitive French poetry and became important primary sources in studies of the language and culture of the Gauls and Celts. So, it does not come as a surprise that when, in March 1805, the new Académie des études celtiques was inaugurated, its secretary thanked Macpherson for having promoted the study of 'Celtic poetry and traditions'. 54

This interest in Gaulish and Ossianic ancestry encompassed both an earnest historical curiosity and a more mythological strand. The activities of the Académie des études celtiques are generally considered to have laid the foundation for fields such as ethnography and anthropology in France. ${ }^{55}$ Nonetheless, several early studies also displayed elements of historical revisionism or myth-making, especially when their authors were eager to establish links with contemporary French society. The French officer and antiquarian Théophile Malo Corret de la Tour d'Auvergne, for instance, claimed in his Origines gauloises (1796) that the Gaulish language and the Erse and Gaelic of the Ossianic poems had a common ancestor in Celto-Breton a language he saw as the principal predecessor not only of French, but also of all European and Asian languages.

Corret de la Tour d'Auvergne's linguistic link between past and present exemplifies how nineteenth-century genealogies functioned in the formation of national identities

50 Deirdre Dawson and Pierre Morère, eds., Scotland and France in the Enligbtenment (Lewisburg, 2004), 19.

51 Deirdre Dawson, 'Fingal meets Vercingetorix: Ossianism, Celtomania, and the Transformation of French National Identity in Post-Revolutionary France', in The Scottish Enlightenment and Literary Culture, ed. Ralph McLean, Ronnie Young and Kenneth Simpson (Lewisburg, 2016), 210.

52 Dawson, 'Fingal meets Vercingetorix', 211.

53 On the origin of the Gaulish genealogy, see Krszystof Pomian, 'Franks and Gauls', in Realms of Memory: Rethinking the French Past, ed. Pierre Nora, trans. Arthur Goldhammer (New York, 1996), $51-5$.

54 See Dawson, 'Fingal meets Vercingetorix, 209.

55 Mona Ozouf, 'L'invention de l'ethnographie française: le questionnaire de l'Académie celtique', Annales, Histoire, Sciences sociales 36/2 (1981), 210-30.

56 Théophile Malo Corret de la Tour d'Auvergne, Origines gauloises, celles des plus anciens peuples de l'Europe puisées dans leurs vraie source, ou recherches sur la langue, l'origine et les antiquités des Celto-Bretons de l'Armorique pour servir à l'histoire ancienne et moderne de ce peuple et à celle des Français (Paris, an V [1796]). 
in France around 1800. After the French Revolution, such identities increasingly depended on what Benedict Anderson has called 'imaginary communities' that privileged horizontal bonds between its members rather than the hierarchically ordained system of the ancien régime. ${ }^{57}$ When construing the history of their nation, these communities relied on stories that articulated historical unity and continuity, especially in situations where this connection with the past had been lost. ${ }^{58}$ The turn-of-thecentury rise of Celtomania in France was one of the ways in which both intellectuals and the government sought to recover this long-lost past.

This identification with Celtic and Ossianic cultures was also encouraged by Napoleon himself. He not only supported the establishment of the Académie des études celtique, but he had also welcomed paintings for his residence at Malmaison that emphasised the link between an Ossianic past and the present of Napoleonic France. One of these was Girodet's aforementioned L'apothéose des héros français (Fig. 1). ${ }^{59}$ To celebrate Napoleon's successes symbolically, Girodet evoked a 'historical' Gaulish people by dressing his bards in furs and Celtic-looking arms and armour this was a significant departure from other Ossianic paintings where garments more closely resembled ancient Roman gear. ${ }^{60}$ Simultaneously, the present is brought into the picture because Ossian is portrayed receiving thirteen identifiable military heroes who had died recently in the French Revolutionary wars. ${ }^{61}$ Rather appropriately, one of these heroes was the aforementioned Corret de la Tour d'Auvergne. A similar strategy to link past and present is employed in the panegyric quoted at the start of this article, where the Ossianic ancestors are looking down on their descendants.

Creating such a link may seem much harder in theatrical productions, especially considering contemporary notions of verisimilitude and historicist representation, for they demanded that the onstage world was depicted as visibly (and sometimes audibly) different from the present. Still, a link between the historical world on stage and the present is guaranteed by the simple reality of theatrical representation, of making something present again in performance. Yet there is more, claimed Joseph Bonet de Treiches, who had been the Opéra's director since 1799 (with some interruptions). In his publication De l'Opéra en l'an XII (1803), he explained that the theatre's ability to unite all the arts was crucial to bringing the past back to life in an uncannily potent and faithful manner. In this respect, he believed the Opéra to surpass all other theatres as well as the art of painting. Discussing Antonio Sacchini's Oedipe à Colonne (1786), the most performed opera of the Napoleonic era, he claimed that it is not an image of Athens, coldly represented

57 Anderson, Imagined Communities, 6-7 and 20-6.

58 Anderson, Imagined Communities, 196-203.

59 Girodet initially conceived of a painting depicting Hercules, but changed the topic to Ossian to complement François Gérard's Ossian évoque les fantômes au son de la barpe sur les bords de la Nora (1801), which was also destined for Malmaison. Cuillé, 'From Myth to Religion in Ossian's France', 250-1.

60 See, for instance, Gérard's Ossian and Jean-Dominique-Auguste Ingres Le songe d'Ossian (1813).

61 See Anne-Louis Girodet, 'Description du tableau', in Oeuvres Posthumes de Girodet-Troison, Peintre d'histoire, suivie de sa correspondence, ed. P.A. Coupin, vol. 2 (Paris, 1829), 289-95.

444 
on a canvas, that the spectator admires in Oedipe. It is Athens itself, its temples, palaces, king, people, customs, celebrations and pleasures. ${ }^{, 62}$ Then he continued by highlighting how each of the arts aided in reviving this ancient city. ${ }^{63}$

Bonet's comparison of opera with painting is illuminating; in contemporary theatre and salon milieus, it was thought that re-enacting a painting, creating a so-called tableau vivant, could increase the educational value of the original visual representation. ${ }^{64}$ The Opéra itself had also partaken in this trend; for instance, the oath scene in the Act II finale of Bernardo Porta's Les Horaces (1800) was designed to recreate Jacques-Louis David's Le serment des Horaces (1785) - a painting that had acquired a strong Republican significance because of its portrayal of brotherhood. ${ }^{65}$ Thus it was a logical step for Bonet to credit the Opéra's tableaux, whether bringing an existing painting to life or not, with eliciting such 'magical effects' that 'moved' audiences and made them 'identify' with the facts and fictions recorded by the ancient Greek and Roman writers. ${ }^{66}$ He even boasted that the vivid impressions left by theatrical representations would be a better school for the French youth than the colleges. Thus, he attempted to claim a central place for theatre and opera (especially when it sought a meticulous coordination between the arts) in the education of patriotic and loyal subjects - a topic that was particularly dear to Napoleon who reformed the entire secondary school system to this end. ${ }^{67}$

\section{Ossian: 'a monument of genius'}

Bonet may have had Le Sueur's Ossian in mind as one of the productions that would realise both the artistic and the political goals of his operatic vision. In late 1803, when he penned De l'Opéra, this work had been in production for at least two years, and he expressed the hope that the success of this 'monument of genius ... will honour

62 Joseph Bonet de Treiches, De l'Opéra en l'an XII (Paris, 1804), 74.

63 Bonet, De l'Opéra, 74.

64 See Kirsten Gram Holmström, Monodramas, Attitudes, Tableaux Vivants: Studies on some Trends of Theatrical Fashion 1770-1815 (Stockholm, 1967), 217-23.

65 Porta himself made clear that he wanted the scene to act out the painting. The score requests that the singers are to take on 'the postures forming the painting' and in a letter to the Opéra's management, he described the scene as: 'Le Serment des David Horaces par David mis en action au théâtre.' Bernardo Porta, 'Les Horaces’ vol. 2, 191. F-Pbmo Mus. MS. A-375 (1-3); and Bernardo Porta aux administrateurs (c.1814). F-Pbnf musique, LA -PORTA BERNARDO-6. Douglas Ipson credibly dates this letter to 1814 and provides a more detailed account of the oath scene's political meaning in Douglas L. Ipson, 'Deadly Tableau: David's Horatii, Porta's Horaces, and the Plot to Assassinate Napoleon, 1800'. Paper read at the AMS Conference Louisville, 15 November 2015. On the education value of oath scenes in patriotic theatre and opera, see M. Elizabeth C. Bartlet, 'The New Repertory at the Opéra during the Reign of Terror: Revolutionary Rhetoric and Operatic Consequences', in Music and the French Revolution, ed. Malcolm Boyd (Cambridge, 1992), 130-2 and 139-49.

66 Bonet, De l'Opéra, 77.

67 On Napoleon's transformations of the secondary school system, see Alexander Grab, Napoleon and the Transformation of Europe (Basingstoke, 2003), 55-9. 
French creative prowess and reinvigorate the prestige of this theatre'. ${ }^{68}$ As Le Sueur was trying to secure the performance of Ossian, he indeed appealed to the Opéra's management, promising a work that would highlight the theatre's ability to unite the arts. And as I will discuss later, he would exploit this ability to create an overwhelming effect in the work's most instructive scene: the dream scene.

Le Sueur's operatic aesthetics as presented in the lengthy Lettre en réponse à Guillard of 1801 foregrounded the need for the union of the arts. ${ }^{69}$ Early on in the essay, he played up this unique characteristic of the Opéra's productions. With his fondness for capitalisation, he proclaimed that 'only in Paris can one truly see a theatre that UNITES ALL THE FINE ARTS, a MAGICAL SPECTACLE because of its effects, THE GRAND OPERA'. ${ }^{70}$ The Lettre contains several passages that witness his commitment to uniting the arts. He suggested that the Opera should emulate the coordination between music and bodily movement achieved at the Opéra-Comique, probably referring to the Théâtre Feydeau where he had experienced his first operatic successes in the 1790s. In this theatre, he said, 'expressive singing [was] united with all the means of tragic pantomime, always in coordination, always in perfect simultaneity with the mimetic indications of the orchestra'. ${ }^{71} \mathrm{He}$ also pleaded for the importance of music and sets in conveying couleur locale. Talking more specifically about La mort d'Adam, another work of his in rehearsal at the Opéra, he declared 'it is necessary that the sets (even when very simple) and the exposition [prelude] transport the listener to a site and to an age where he might himself be able to desire and demand the songs of the first age of men. ${ }^{72}$ This emphasis on the union of the arts was perhaps necessary to convince the Opéra's management that despite his reputation as first and foremost an opéra comique composer, his works would be a success at the Opéra. ${ }^{73}$ After all, Ossian had initially been conceived for the Théâtre Feydeau; its production had allegedly reached the final rehearsal stages when its premiere was cancelled following

68 Bonet, De l'Opéra, 49. In these hopes, Bonet was later joined by Jean-Baptiste-Charles Legendre de Luçay, the governmental official overseeing the Parisian theatres. See Jean-Baptiste-Charles Legendre de Luçay to Bonet, 22 messidor an XII (11 July 1804). F-Pan AJ ${ }^{13} 90$.

69 Jean-François Le Sueur, Lettre en réponse à Guillard sur l'opéra de la 'Mort d'Adam' dont le tour de mise arrive pour la troisième fois au Théâtre des Arts et sur plusieurs points d'utilité relatifs aux arts et aux lettres (Paris, brumaire an X [October 1801]). The Lettre was at least in part invoking the tradition of the eighteenth-century querelles over theatrical and operatic styles, yet it largely failed to elicit an aesthetic debate. Instead it unleashed a fierce and personal conflict between Le Sueur and Bernard Sarrette, the director of the Conservatoire, that eventually resulted in the dismissal of the composer as Inspecteur at the Conservatoire. The quarrel, nevertheless, had its aesthetic grounds, as Le Sueur and Sarrette had very different visions about the future of French music, with the former privileging opera and the latter instrumental music. See Rebecca Geoffroy-Schwinden, 'Politics, the French Revolution, and Performance: Parisian Musicians as an Emergent Professional Class, 1749-1802' (PhD diss., Duke University, 2015), 113-14.

70 Le Sueur, Lettre en réponse à Guillard, 16.

71 Le Sueur, Lettre en réponse à Guillard, 52.

72 Le Sueur, Lettre en réponse à Guillard, 33 (emphasis in original), see also 17.

73 Le Sueur's three opéras comiques are discussed extensively in Jean Mongrédien, Jean-François Le Sueur: contribution à l'étude d'un demi-siècle de musique française (1780-1830), vol. 1 (Bern, 1980), 217-455. 
the bankruptcy of Charles-Barnabé Sageret, the Feydeau's director. ${ }^{74}$ Still, Le Sueur used the Lettre to contend that his principal artistic ambition to unite the arts would make his operas the perfect vehicles to revitalise the prestige of the Opéra - an opinion later shared by the Opéra's director Bonet as well, as mentioned earlier. ${ }^{75}$

Even though the Lettre focuses on La mort d'Adam, Le Sueur's aesthetic programme was first fully realised in the production of Ossian. The three extant manuscript libretti for Ossian written between 1798 and 1803 bear out Le Sueur's aesthetic ideas: they provide ample information about how the different arts were to contribute to the work's performance. The manuscripts are full of lengthy descriptions of costumes, pantomimic scenes and striking theatrical effects, such as the detonation of a bridge and the dream scene. ${ }^{76}$ From the very beginning, each version also shows the authors' detailed attention to Ossianic couleur locale. The opening scene is conjured up with myriad details calling for dark, mountainous forests in the background and, for the front of the stage, an ancient building with armour, harps and other bardic instruments displayed on its walls. Two of the libretti even specify that the sets should depict the renowned cave of Fingal, a cave discovered in Scotland in 1782 where Ossian's father supposedly hid from his enemies. These descriptions far exceeded the customary length and detail found in other opera manuscripts and in the surviving printed libretti of Ossian's two librettists, Paul Palat-Dercy and Jean-Marie Deschamps. ${ }^{77}$ Therefore, these libretti suggest a changing attitude to how composer and librettist were to create an opera: they were no longer to treat the staging as

74 Le Sueur discussed the progress of Ossian at the Feydeau and then at the Opéra in a document, largely contemporary with the Lettre, entitled 'Époque de la réception de cet opéra au Théâtre des arts' (c.1801). F-Pbnf musique Rés F 1219 (2).

75 Le Sueur, Lettre en réponse à Guillard, 13-15.

76 These manuscript libretti represent three different stages of Le Sueur's opera. The text of the oldest manuscript copy (F-Pbnf musique 7884) alternates between prose and verse and thus likely preserves the opéra comique version in rehearsal at the Feydeau in 1798. It contains several indications in Le Sueur's hand for transforming the text into a more spectacular and sung-through opera. The second manuscript (F-Pan $\mathrm{AJ}^{13}$ 90) may have been one of the versions presented to the Opéra's jury de l'art between 1800 and 1803 . The text is now entirely in verse and some scenes have been expanded or cut, but it largely retains the structure of the 1799 version. The third manuscript (F-Pbmo Rés 592) reflects the libretto as rewritten by Jacques-Marie Deschamps after Paul (pseudonym for Alphonse-François) Palat Dercy had passed away in 1802. It cites both authors on the front page, includes numerous comments in Deschamps's hand, and displays a number of changes that Le Sueur was advised to undertake by the Opéra's director, Étienne Morel de Chédeville, in May 1803. See the letter from Étienne Morel de Chédeville to Le Sueur on 11 prairial an XI (31 May 1803) quoted in a letter from Jean-Marie Deschamps to Luçay, 1 vendémiaire an XII (24 September 1803). F-Pan $\mathrm{AJ}^{13} 90$.

77 A note of caution is warranted when comparing manuscript libretti with printed ones because the former usually contain lengthier scene descriptions to convey the full spectacle to the literary jury. Unfortunately, I have not been able to locate any other manuscript libretti by Dercy or Deschamps for comparison. In general, little is known about Le Sueur's two librettists. Paul Palat Dercy had already worked with Le Sueur in the 1790s on two opéras comiques: La caverne (1793) and Télémaque (1796). He died in 1802, after which Jacques-Marie Deschamps took on the responsibilities of revising the libretto. Deschamps was a prolific writer, having tried his hand at many different genres of theatre and literary translation. He also became secretary of Joséphine de Beauharnais. For the Opéra, he primarily worked on smaller works and pasticcio oratorios, often in collaboration with Etienne Morel de Chédeville and Jean-Baptiste-Denis Desprès. See Spire Pitou, 
ancillary to a self-sustaining score, but should consider the visual aspects of staging as essential elements of their own conception. None of the libretti is in Le Sueur's hand; still, the composer's attention to staging details in his annotations in the oldest libretto, and the aesthetic programme set out in the Lettre, indicate that he was an important influence on the emergence of this attitude.

With their conspicuous integration of text, character movement, and set and costume design, the manuscript libretti of Ossian appealed to the diverse team of artists in the Opéra's new jury de l'art. The jury's first report concluded that it offered 'beautiful spectacle, and ... much action, felicitous oppositions, and moving situations' ${ }^{78}$ The second report even indicated that the libretto promised sufficient musical and visual spectacle to mask its literary deficiencies; they declared that 'this work's success will primarily depend on the musicians and the set designers ... it has to be considered a rich and brilliant pantomime explained in a few words. ${ }^{79}$ Confirmation from the jury that the literary flaws of a libretto would be redeemed by the spectacle, may seem surprising. ${ }^{80}$ Yet such reports indicate that even the literary jury considered these libretti as representations of future performances. Moreover, they show that Ossian was considered a suitable vehicle to exploit the theatre's supposedly unique ability to unite the arts and hence restore its reputation as Bonet and others hoped.

\section{Staging a new genealogy}

Le Sueur's emphasis on coordinating the arts and couleur locale in Ossian was also linked to the new place of the bards in French genealogies. Like several of his contemporaries, the composer believed them to be French ancestors. ${ }^{81} \mathrm{He}$ even went so far as to suggest a link between the bards' epic recitations and French opera:

The Paris Opéra: An Encyclopedia of Operas, Ballet, Composers and Performers. Rococo and Romantic, 17151815 (Westport, CT, 1985), 151 and 153-4.

78 Jury report of Ossian, ou les bardes, 2 fructidor an VIII (10 August 1800) copied in 'Délibérations du Jury report of Ossian, ou les bardes, 2 fructidor an VIII (10 Ausus
jury de littérature', an VII-XI [1798-1802]. F-Pan AJ ${ }^{13} 44$.

79 'Rapport du jury' [17 floréal an IX (7 May 1801)]. F-Pan $\mathrm{AJ}^{13}$ 90. The jury report itself is not dated, but its contents resemble a summary of the jury decision on 17 floréal an IX as recorded in the 'Délibérations'.

80 This tension between literary aspirations and a demand for spectacle had been part and parcel of the Opéra's existence since its very beginnings. The emphasis on spectacle tended to be denounced by intellectuals, and so the Opéra's management and some of its artists usually tried to highlight the genre's literary qualities. See Johnson, Backstage at the Revolution, 119-47.

This long-standing association of the Opéra with supposedly empty spectacle was also exploited by the Comédie Italienne during the 1780 s as the latter theatre sought to distinguish its new employment of stage technology in its productions. See Julia Doe, 'Opéra-Comique on the Eve of Revolution: Dalayrac's Sargines and the Development of "Heroic" Comedy', Journal of the American Musicological Society 68/2 (2015), 339-40.

81 This belief is attested in the opening of Le Sueur's 'historical essay on the bards'. Jean-François Le Sueur, 'Essai historique sur les bardes, leurs mœurs et leurs coutumes, avec une exposé des usages, des opinions, des fêtes et des costumes des peuples chez lesquels ils vivoient, pour servir aux mœurs, costumes, fêtes, pantomimes et décorations à suivre dans l'opéra d'Ossian', [1801-4?], f. 1r. F-Pbnf Musique Rés F1219(2). 
The poems of Ossian, like those of all ancient bards, were made of simple measured verses without rhythm or rhyme. ... the bards kept rhyme and rhythm - corresponding to the combination of long and short [syllables] - for the lyric pieces with which they interspersed their works at every page. In these places, they introduced regular songs, airs that they supported with a continuous accompaniment of their harps, to interrupt their narrative and grab the attention of their spectators. These narratives may have resembled our modern recitative. ${ }^{82}$

This excerpt underscores that Le Sueur actively participated in creating the genealogical narratives that had fuelled turn-of-the-century Ossianism; he pointed to an alternative genealogy of opera as native to France (instead of Ancient Greece or Renaissance Italy).

The composer made these genealogical claims in the 'Essai historique sur les bardes, leurs mours et leurs coutumes' ('Historical Essay on the Bards, their Morals and Customs'), a document written between 1801 and 1804 in which he compiled historical information on the Ossianic bards. The 'Essai' was presented as crucial to the staging of Ossian and its couleur locale: its first page specified that this was 'a report on the practices, opinions, celebrations, and costumes of the people with whom [the bards] live to inform the morals, costumes, celebrations, pantomimes, and sets that are to be followed in the opera of Ossian, ${ }^{83}$ With this specification, Le Sueur may have sought to underline the historical legitimacy of the essay (and by extension of Ossian's staging), for it mirrored titles found in contemporary studies of historical societies. ${ }^{84}$

The content of the 'Essai' is furthermore a testimony to Le Sueur's investment in historical precision: it comprises quotations of Macpherson's works and of their accompanying historical commentaries, most prominently Hugh Blair's Critical Dissertation on the Poems of Ossian (1761), and the introductions to the Italian translation by Melchiorre Cesarotti (1773) and the French one of Pierre Letourneur (1777). In a few instances, Le Sueur even supported his description of bardic life with quotes ascribed to contemporaries of the ancient bards such as the first-century Roman poet and historian Lucan (39-65). ${ }^{85}$ Much of this information was cited to underscore the historicity of certain plot events and set and costume descriptions in Ossian.

82 Le Sueur, 17r. Also quoted in Charlton, 'Ossian, Le Sueur and Opera', 42 and Mongrédien, 'Ossian à l'Opéra (1804)', 549. Charlton suggests that this description of bardic music allowed Le Sueur to move rather flexibly between recitative and aria in Ossian.

83 Le Sueur, 'Essai historique sur les bardes', 1r.

84 See, for example, Jean Picot, Histoire des Gaulois depuis leur origine jusqu'à leur mélange avec les Francs et jusqu'au commencement de la Monarchie Françoise suivi de détails sur le climat de la Gaule, sur la nature de ses productions, sur la caractère de ses habitans, leurs mours, leurs usages, leur gouvernement, leurs lois, leur réligion, leur langage, les sciences et les arts qu'ils ont cultivés etc. (Genève, an XII - 1804).

85 For instance, he reproduced the following quote 'bardi apud gallos virorum fortium laudes decantabant', a slightly abbreviated version of 'bardi apud gallos vates erant aut philosophi, qui virorum fortium laudes decantabant' ('the bards among the Gaulish poets were also philosophers, who sang the praises of brave men'). The latter is ascribed to Lucan in F. Ambrosi Calepini Bergomensis, Dictionarium Septem Liguarum (Venice, 1635), 36. For Le Sueur's quote see his 'Essai historique sur les bardes', $5 \mathrm{v}$. 
Yet Le Sueur did not limit himself to researching plot and visual elements; he also attempted to reconstruct a historical, third-century bardic sound. Some kind of Ossianic couleur locale had already been experimented with in turn-of-the-century romances inspired by Macpherson's poems: they usually featured a harp accompaniment as in Étienne Nicholas Méhul's 'Oscar et Dermide'. ${ }^{86}$ Le Sueur readily exploited this customary association by requesting twelve harps in his score, specifying that they 'dominate the orchestra and reproduce the effect of the hundred harps of Selma' - referencing a performance practice described by Macpherson. ${ }^{87}$ This indication signals that the composer's main goal was reconstructing the bards' musical customs and he was less concerned with communicating the sombre atmosphere of the poems' tenebrous Scottish setting (as was probably Méhul's aim when he omitted the high strings in his Ossianic opera of 1806, Uthal). ${ }^{88}$

In the absence of sources featuring third-century bardic music, Le Sueur used insights from eighteenth-century theories and philosophies on the origins of language and music to reconstruct their melodies and harmonies. Among these were Esteban de Arteaga's Le rivoluzioni del teatro musicale italiano (1783-8) and especially, as David Charlton has noted, Jean-Jacques Rousseau's Essai sur l'origine des langues (1781) and Dictionnaire de la musique (1786). ${ }^{89}$ Following these sources, Le Sueur assumed that the bards' music must have been based on imitation: it had developed out of their earliest form of language, which had in turn emerged from a tonal and rhythmic copying of sounds and images in nature. ${ }^{90}$ Their melodies, the composer decided, would thus have been characterised by an 'expressive nature and sublime simplicity'. Harmony, in contrast, was a secondary element, which served largely to support the words' meanings. ${ }^{91}$ According to the composer, 'abstract' music and complicated harmonic structures were to be avoided, for they signalled a culture that was becoming 'scientific' and distant from nature. ${ }^{92}$ Thus, while Le Sueur's

86 Étienne-Nicholas Méhul, 'Oscar et Dermide. Chant Gallique imité d’Ossian', in Deuxième Recueil de six romances de différents auteurs (Paris, 1796), 12. The text is by François Arnault, who claimed this piece had given him the inspiration for his tragédie, Oscar fils d'Ossian (1796). On Ossianic romances, see Emmanuel Reibel, Comment la musique est devenue 'romantique': de Rousseau à Berlioz, (Paris, 2013), 128-9.

87 Le Sueur, Ossian on les bardes, 541. This custom was mentioned in James Macpherson, Fingal, Book VI (London, 1765), 111 and 119.

88 Étienne-Nicolas Méhul, Uthal (Paris, 1806).

89 Charlton, 'Ossian, Le Sueur and Opera', 42-4. Charlton seems to doubt that Le Sueur was earnestly interested in recovering the music of the bards, and proposes that the composer had a more recent operatic model in mind when creating their music: Rousseau's Le devin du village (1752). He points out that one of the dream scene melodies is the minor version of the first aria of the latter work and characterises the Caledonians as 'noble savages after Rousseau's own musical model, whose optimism and regularity of musical language bear no close resemblance to folk utterance'.

90 Le Sueur, 'Essai historique sur les bardes', $14 \mathrm{v}$.

91 Le Sueur, 'Essai historique sur les bardes', 17v (on the primacy of melody) and 18r (on their use of harmony).

92 Le Sueur, 'Essai historique sur les bardes', 14v-15r. On the early nineteenth-century debate about melody and harmony as well as whether music's highest goal is to imitate nature, see, for example, Michael Fend, Cherubinis Pariser Opern (1788-1803) (Stuttgart, 2007), 114-39. 
thorough investment in recreating bardic music was unprecedented for the time, his method was one borrowed from the older philosophe tradition: he assumed that the origins of language and music could be recovered through philosophical research rather than empirical ethnography, for instance, of Scottish folk music. ${ }^{93}$

Le Sueur's imitation-based conception of bardic music inspired an intricate connection between text, music and image in the opening chorus of Ossian. The verses themselves are already replete with nature descriptions:

Que le rivage retentisse

De nos accents harmonieux.

Soleil, quitte le sein de l'onde

Parais sur le sommet des monts

Chasse l'obscurité profonde

Qui règne encore dans nos vallons.

Cesse d'attrister la nature,

Bruit sourd \& lugubre des vents

Que des zéphirs le seul murmure

Se mêle à nos mâles accents. ${ }^{94}$
Let the riverbank resound

With our harmonious songs.

Sun, abandon the bosom of the wave,

Appear on the mountain tops,

Chase away the heavy darkness

That still reigns in our valleys.

Stop saddening nature,

Dull and dreary sound of the winds

So that only the murmur of zephyrs

Joins our virile songs.
749

750

751

752

753

754 

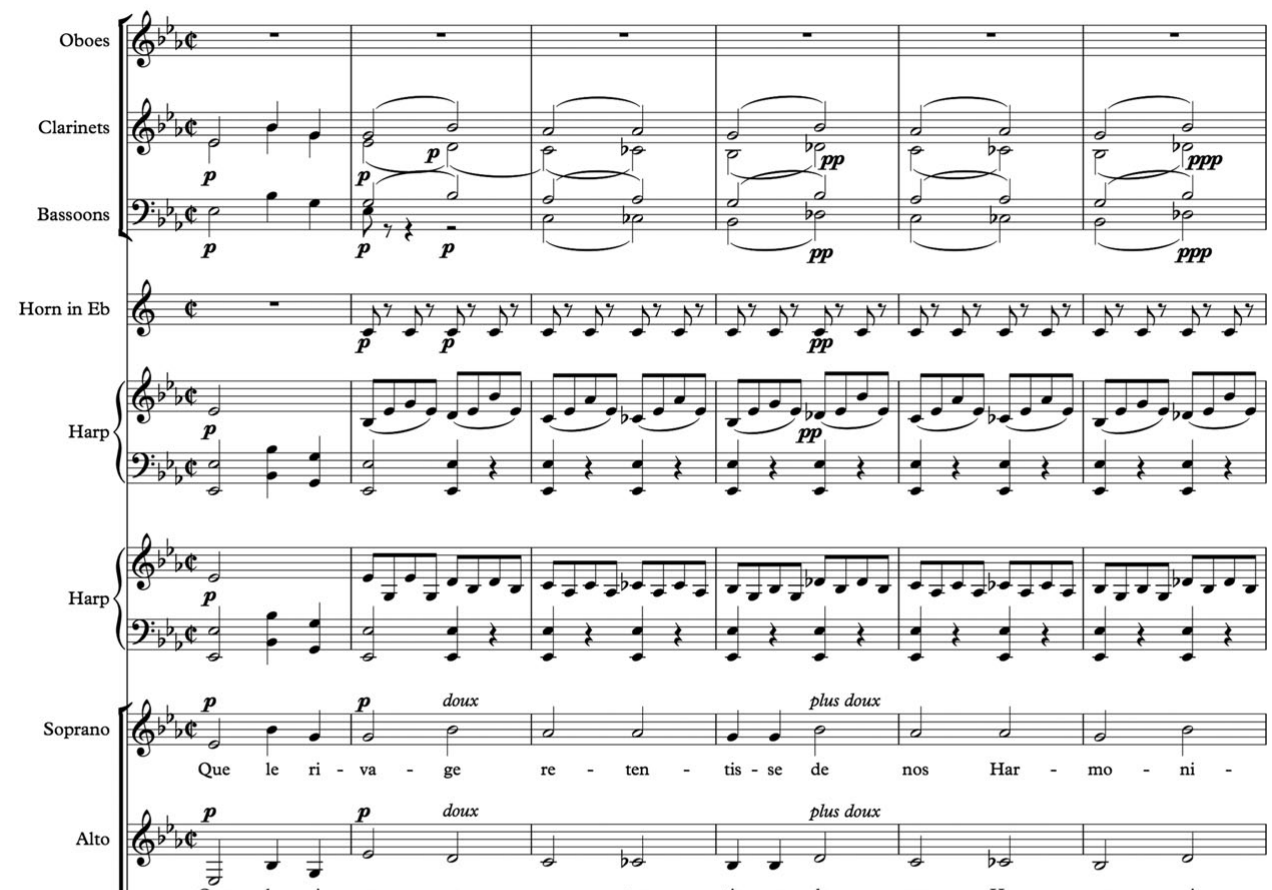

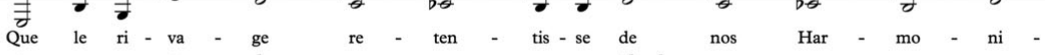

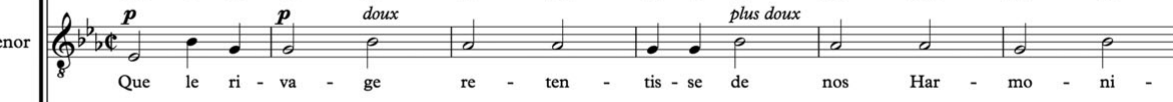

Ex. 1: 'Le Chant de la nuit, Chant de Selma' ('Song of the night, song of Selma'): the opening 


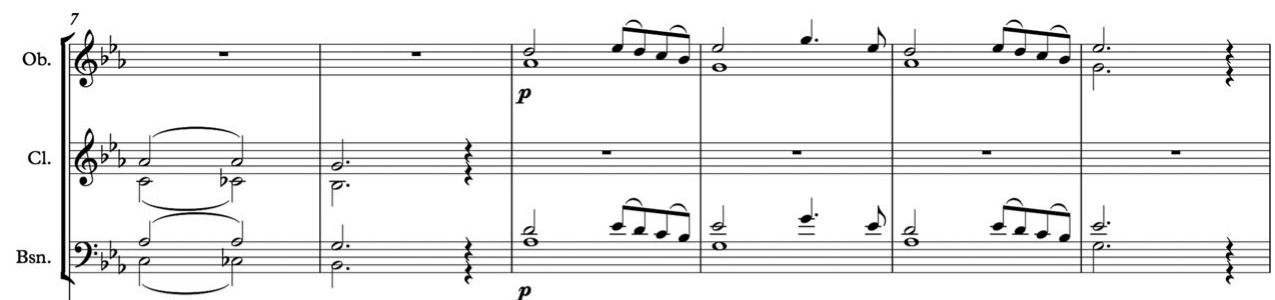

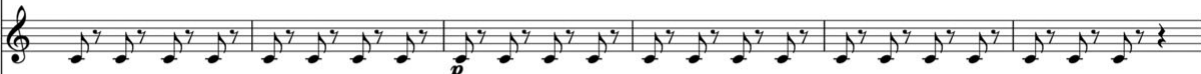

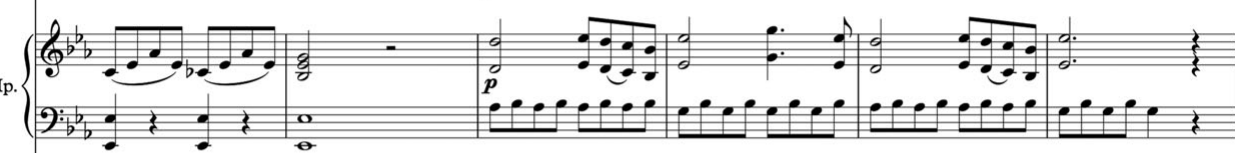

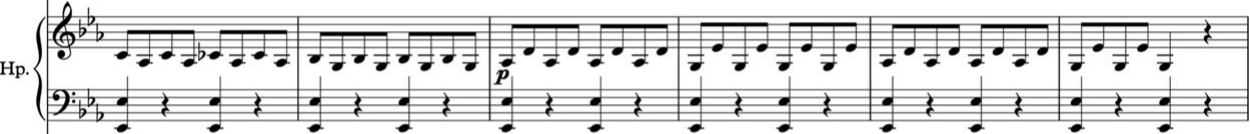

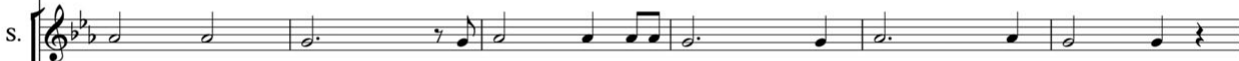

eux ac - cens So-leil quit - te le sein le sein l'on
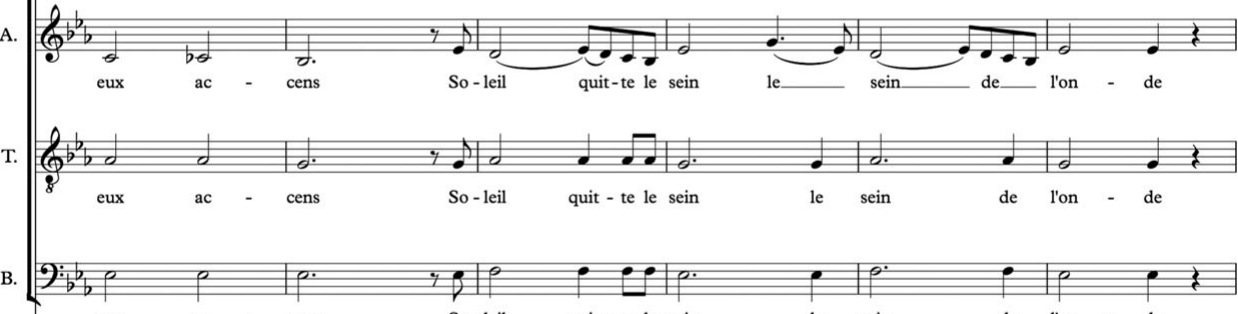

Ex. 1: Continued. 


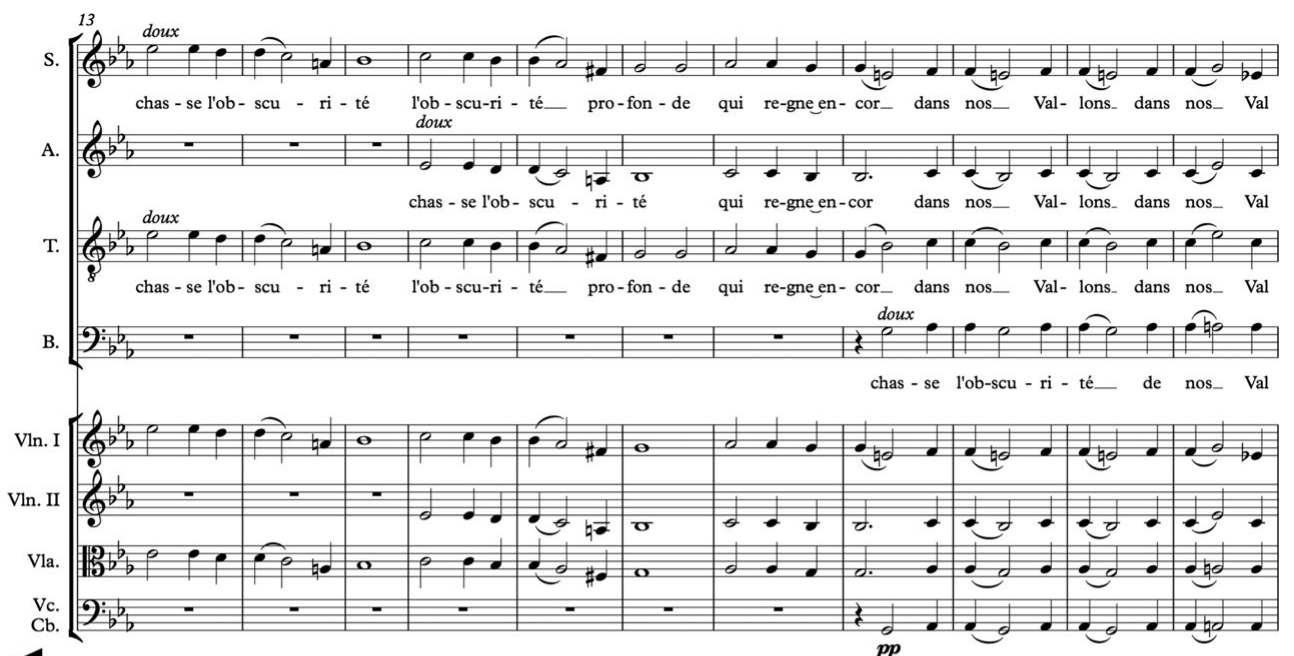

Ex. 1: Continued. 


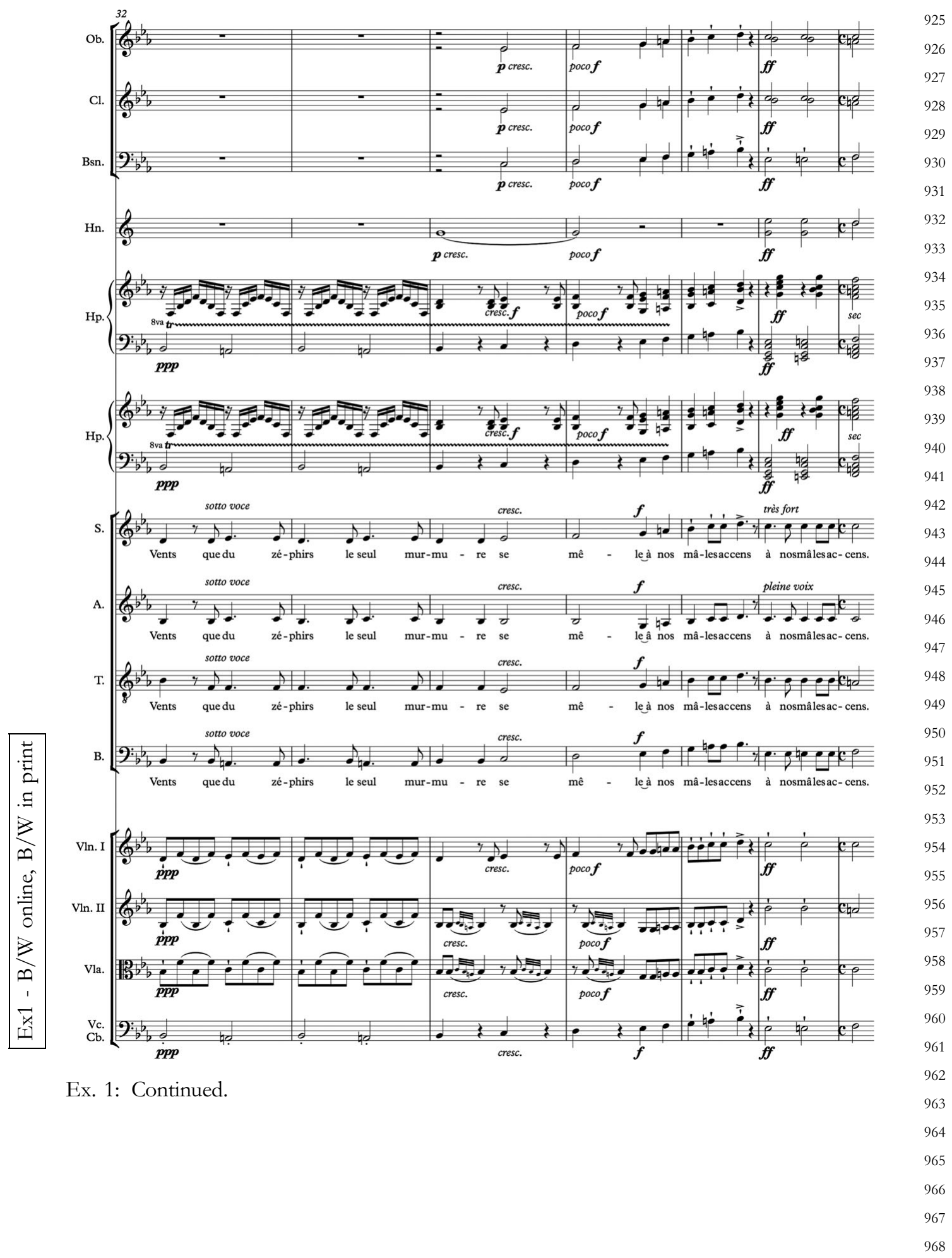


represented by the sudden reduction of the full orchestra to a unisono line in the high strings and voices (b. 13). ${ }^{98}$ The contours of the ensuing syncopated rhythms look like valleys (bb. 20-3), and the fast swell to fortissimo and then sudden drop to pianissimo in the string tremolos resemble the winds' dull and dreary sounds (bb. 25, 29). Suspensions in the soprano line, traditionally used to represent sadness, suitably accompany the verse 'cesse d'attrister la nature' (bb. 25-31). The 'zéphirs' seem to be imitated in the harp arpeggios (bb. 32-3), and their murmuring may have prompted the indication 'sotto voce' for the chorus (b. 32). Finally, the assumed virility of the song is emphasised by the spiccato notes, accents and the request to sing with a 'full voice' (bb. 36-8).

With the integration of text, music and staging in the opening chorus, Le Sueur may earnestly have intended to recreate a historically researched version of ancient bardic music. Nevertheless, it is likely no accident that this integration also highlighted the Opéra's unique artistic prowess at uniting all the arts. Moreover, by suggesting a similarity and possible genealogical link between Ossianic recitation and French opera as based in the coordination of the arts, his opera firmly positioned itself within post-Revolutionary attempts to claim Ossian as a French ancestor.

\section{The dream scene's political programme}

Reimagining the artistic genealogy of French opera was only one aspect of Ossian's engagement with post-Revolutionary nation-building; several links created between past and present specifically concern the political situation in France around 1800. As mentioned, David Charlton and Tili Boon Cuille have pointed out that the libretto contains clear references to Napoleon's attempts to restore peace with the Roman Catholic Church. ${ }^{99}$ This is especially noticeable in the addition of a religious dimension to the conflict between the bards and Scandinavians, who imposed their cult of Odin - a dimension completely absent from Macpherson's Ossianic world and the earlier opéra comique version of Ossian. ${ }^{100}$ Moreover, in a passage added to the final version of the opera's finale, a conspicuous connection is made to the

98 As the weakest example of imitation, the ascending sequence may only be an accidental illustration of the sunrise. In an earlier version of this chorus that was performed at a concert on 14 April 1802, this melody set the line 'que la harpe à nos voix s'unisse' (that the harp may unite with our voices). The sunrise and mountain in this version are more distinctly depicted by a leap of a seventh in the soprano to the highest note in the piece $\left(\mathrm{a}^{2}\right)$ and a subsequent plunge of an eleventh. 'Concert figurant les fêtes du Palais de Selma'. F-bmo, Mat. 19 [191 (70-3).

99 Charlton, 'Ossian, Le Sueur and Opera', 45-6 and Cuillé, 'From Myth to Religion in Ossian's France', 251-2.

100 References to the cult of Odin are completely absent from the opéra comique libretto (F-Pbnf musique 7884), where the dream scene is also no more than a short prophetic chorus about Ossian's glorious future and does not depict a fully developed heavenly realm. Throughout the following three versions (the two other manuscript libretti and the printed libretto), this religious dimension increases considerably in both the dream scene's depiction of a bardic afterlife and the Scandinavians' cult. This suggests that it was likely added to create a link with Napoleon's efforts to make peace with the Catholic Church, which were ongoing as Ossian was in rehearsal at the Opéra. 
Concordat of 1801: it prophesies that a ruler will arise who 'will cherish the religion that one tried to take away from us', a reference found only in the final printed version of the libretto. ${ }^{101}$

In this respect, the opera resembles Girodet's L'apothéose des héros francais, which is thought to celebrate the same event. Resemblances between the painting and the opera are found not only on the thematic level, but also in the visual depiction. Charlton remarks that the dream scene and painting are both illuminated by meteors. ${ }^{102}$ This can be understood as a clear reference to Napoleon, who had famously proclaimed in a text on happiness presented at the Academy of Lyon in 1791 that 'men of genius are meteors destined to burn to enlighten their era'. ${ }^{103}$ Moreover, Girodet and Jean-Simon Berthélémy, Ossian's costume designer, both attempted to give the characters a 'bardic' appearance by including Celtic-looking armour and garments (see Fig. 2). ${ }^{104}$ One particular sketch of Berthélémy, marked 'for the dream', also shows two women whose body postures and hair are reminiscent of the female figures in the painting (see Fig. 3). There is evidence that the resemblance was more than a coincidence. Sometime after L'apothéose des héros français had been exhibited at the Salon in 1802, Bonet asked the Opéra's artists to redesign the sets, costumes and machines for Ossian to reflect in a more suitable manner the grand nature of Le Sueur's composition. ${ }^{105}$ The elaborate new designs required the Opéra to engage several more painters, and Girodet's name appeared on a few documents in their studios from October $1803 .{ }^{106} \mathrm{He}$ may thus have been one of the extra painters hired to get the sets ready in time.

Given that the dream scene thus takes on some characteristics of a tableau vivant, it is not surprising that it was also the opera's most didactic part. Like the painting, it conspicuously promotes patriotic martyrdom - a message undoubtedly useful to a government that depended on military victories for its legitimacy and thus sent millions of young Frenchmen to their early graves. ${ }^{107}$ The chorus that opens and closes the scene clearly proclaims this message:

Heureux, dans les combats, qui jeune Happy he who dies in combat still encore, succombe young

101 Charlton, 'Ossian, Le Sueur and Opera', 45.

102 Charlton, 'Ossian, Le Sueur and Opera', 47.

103 Le discours de Lyon par le lieutenant Napoléon Bonaparte, introduction by Édouard Driault (Paris, 1929), 81.

104 [Berthélémy], 'Neuf plaques de costumes'.

105 See letters from Bonet to Le Sueur and the set designers of the Opéra on 21 vendémiaier an XII (14 October 1803). F-Pan AJ 90.

106 See letter from the director to Chaignin, Robert, Ménagion, Valenciennes, Girodet, Berthélémy, Crotain, Dégotty, Moench, Le Sueur, Boulet, 2 brumaire an XII (25 October 1803). F-Pan AJ ${ }^{13}$ 90.

107 According to historian David Bell, Napoleon could sustain his position and popularity with the French people only by a continuous string of military victories, see David A. Bell, Napoleon: A Concise Biography (New York, 2015), 49, 80-3 and 93. 


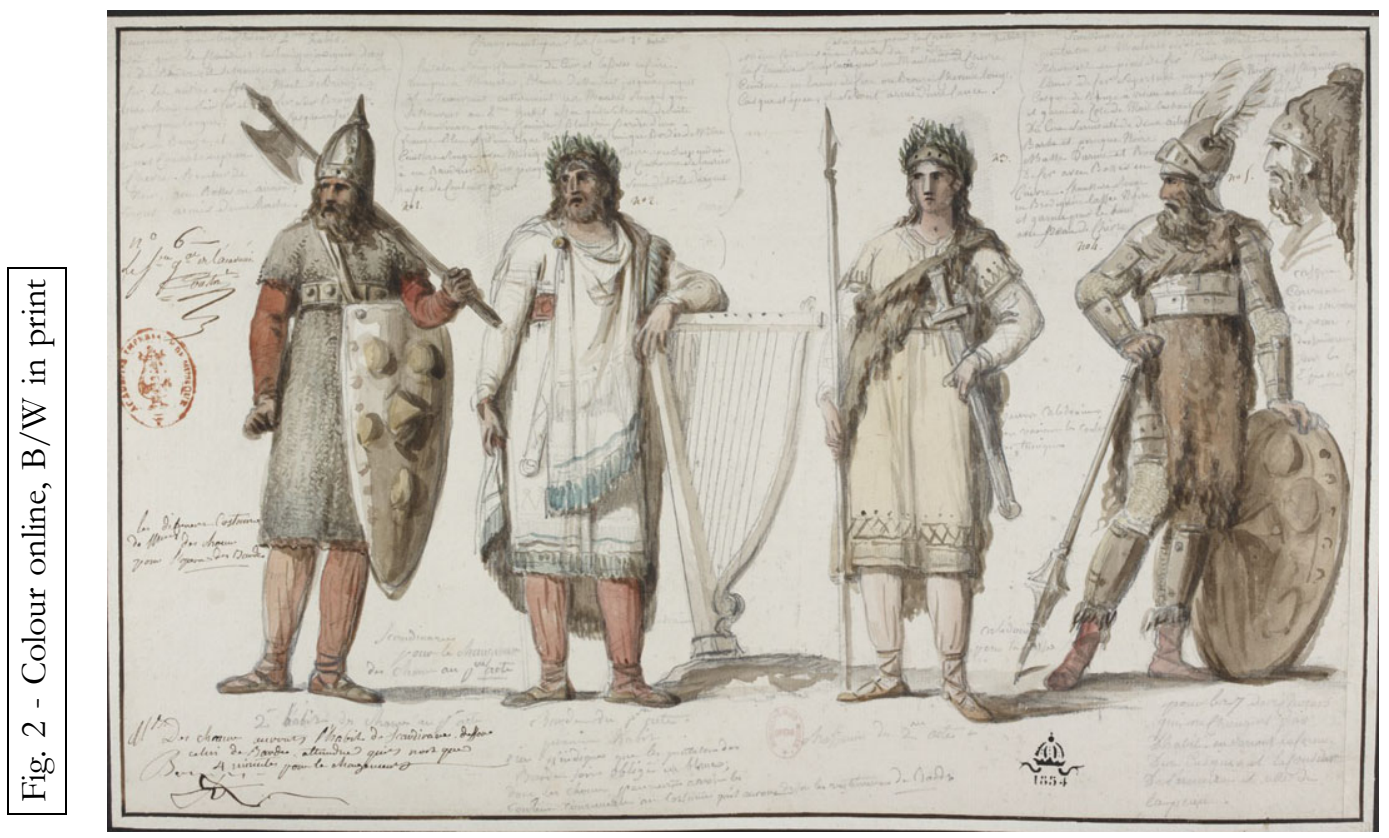

Fig. 2: These sketches show the use of furs and Celtic gear to convey the couleur locale in the costumes for the bards and the Scandinavians in Ossian (Jean-Simon Berthélemy, Costume Designs; Paris, Bibliothèque-musée de l'Opéra).

Quand on vante par-tout sa gloire et When everywhere his glory and talents ses talents are praised.

On n’insultera point à ses débiles He will not be insulted in his senile ans; years;

Et l'amour, l'amitié gémiront sur sa And love, friendship will moan on his tombe. grave.

Mais le vieillard, hélas! Nul regret ne But the old man, alas! No mourning l'attend: awaits him:

Il tombe après ses fils, et reste sans He falls after his son, and remains hommage; without homage;

Comme un chêne ignoré sur un Like an ignored oak on a distant shore lointain rivage;

Le passant voit sa chûte, et s'éloigne The passer-by sees his fall, and departs en chantant. ${ }^{108}$ 

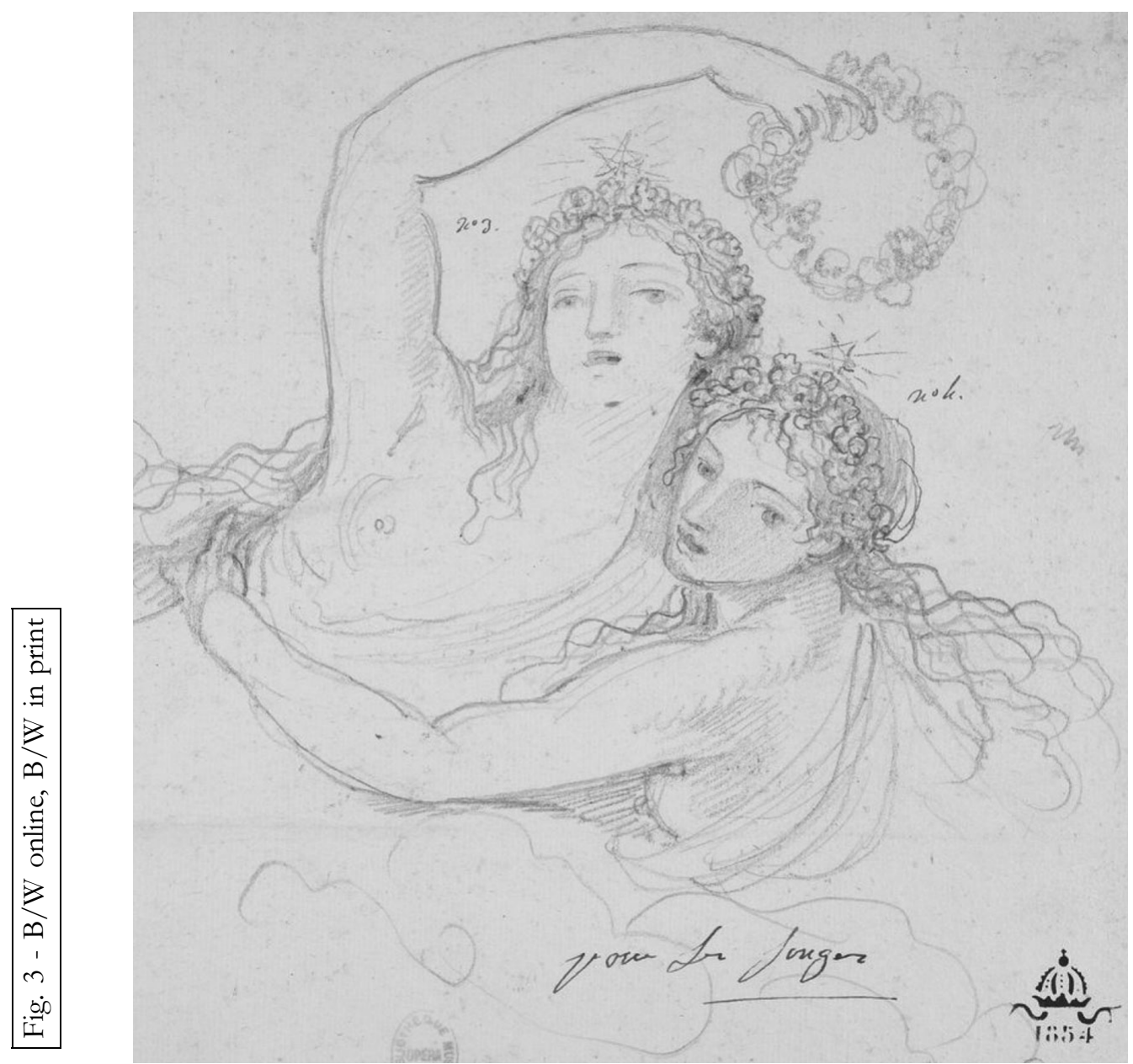

Fig. 3: This sketch for Le Sueur's Ossian titled 'For the Dream' shows two figures in postures and gear similar to that of the women in Girodet's L'apothéose des héros français. The inclusion of half-naked figures and their dynamic poses are quite unusual for costume designs at the Opéra (Jean-Simon Berthélemy, Costume Designs; Paris, Bibliothèque-musée de l'Opéra).

As mentioned in the introduction, the Opéra's artists had joined forces to create a scene that conspicuously showed off the coordination between the different arts and thus would bring this message to life. The choreographer, Pierre Gardel, had arranged the performers according to height - with the taller ones at the front and the shorter at the back. In so doing, his choreography supported the suggestion of greater depth achieved through the accelerated perspective in the painted backdrops. ${ }^{109}$ In the printed score, Le Sueur requested meticulous audio-visual 
coordination: numerous scene descriptions detailed the general synchronisation of musical passages with the unveiling of each new part of the aerial palace, and the tight synchronisation of musical motifs with the movement of individual singers and dancers. In a section where the choir prophesies Ossian's glorious future before he arrives at the grave like a shining star, the composer indicated that the gestures of seven groups of celestial virgins should be coordinated with the seven imitative entrances of the choir (see Ex. 2). He also created the impression musically that this scene was set apart from the opera's plot reality by composing out a transition to and from the dream: pianissimo unison harp and string figuration accompanies the appearance of the cloud panels that mark the passage to and from the Ossianic Heavens (see Ex. 3). These sounds had specific significance in the Ossianic world: harp tones, when elicited by natural phenomena such as wind, were considered to symbolise the ancestors' voices. In the context of the aforementioned writings of Bonet and Le Sueur, at least one reason for this meticulous coordination between the arts would have been to give the dream the heightened potential to 'transport' audiences and thereby have an educational impact.

The scene's instructive message would likely have been strengthened further by similarities with celebrations of patriotic martyrdom in the Revolutionary festivals. The scene had, for instance, elements in common with the civic festival organised in 1793 to inaugurate the busts of the Revolutionary 'martyrs' Jean-Paul Marat and Louis-Michel le Peletier. ${ }^{110}$ On that occasion, the Opéra had been transformed into a 'temple of arts and liberty' and the use of the priests' chorus from Gluck's Alceste had given the event a religious aura - an aura that can also be perceived in the music for the bardic heavens in Le Sueur's opera, which included a cappella choral sections, modally inflected melodies and plagal cadences. ${ }^{111}$ In both instances, the choreographer Gardel had made use of 'young virgins in white tunics' descending steps and honouring the deceased patriotic heroes by strewing garlands around them. More generally, the dream shared with Republican festivals the focus on the how civic duties were interwoven with domestic ones: Ossian's heroism is depicted as important for the flourishing of bardic society and the happiness of his loved ones. Towards the end of the dream scene, Rosmala is shown in tears on Ossian's grave, singing a melody from her Act II love duet, but now lamenting his death and her imprisonment by the enemy. ${ }^{112}$ As historian James Livesey has argued, showing how domestic and civil duties were intertwined had been especially characteristic

110 For the description of this festival, see Almanach des spectacles (Paris, an III [1794]), 100-1.

111 Le Sueur, Ossian on les bardes, 405-6 (a cappella chorus), 399-400 and 411 (aeolian inflected melodies), and 398 and 428 (plagal cadences). Mongrédien also explicitly points out the complex religious number symbolism that underlies the structure of the dream scene. Mongrédien, 'Ossian à l'Opéra (1804)', 97-8.

112 The score even highlights the connection to Act II by requesting that it is performed 'a little slower, but with the same tone and the same character as in the second act'. Le Sueur, Ossian ou les bardes, 411. 


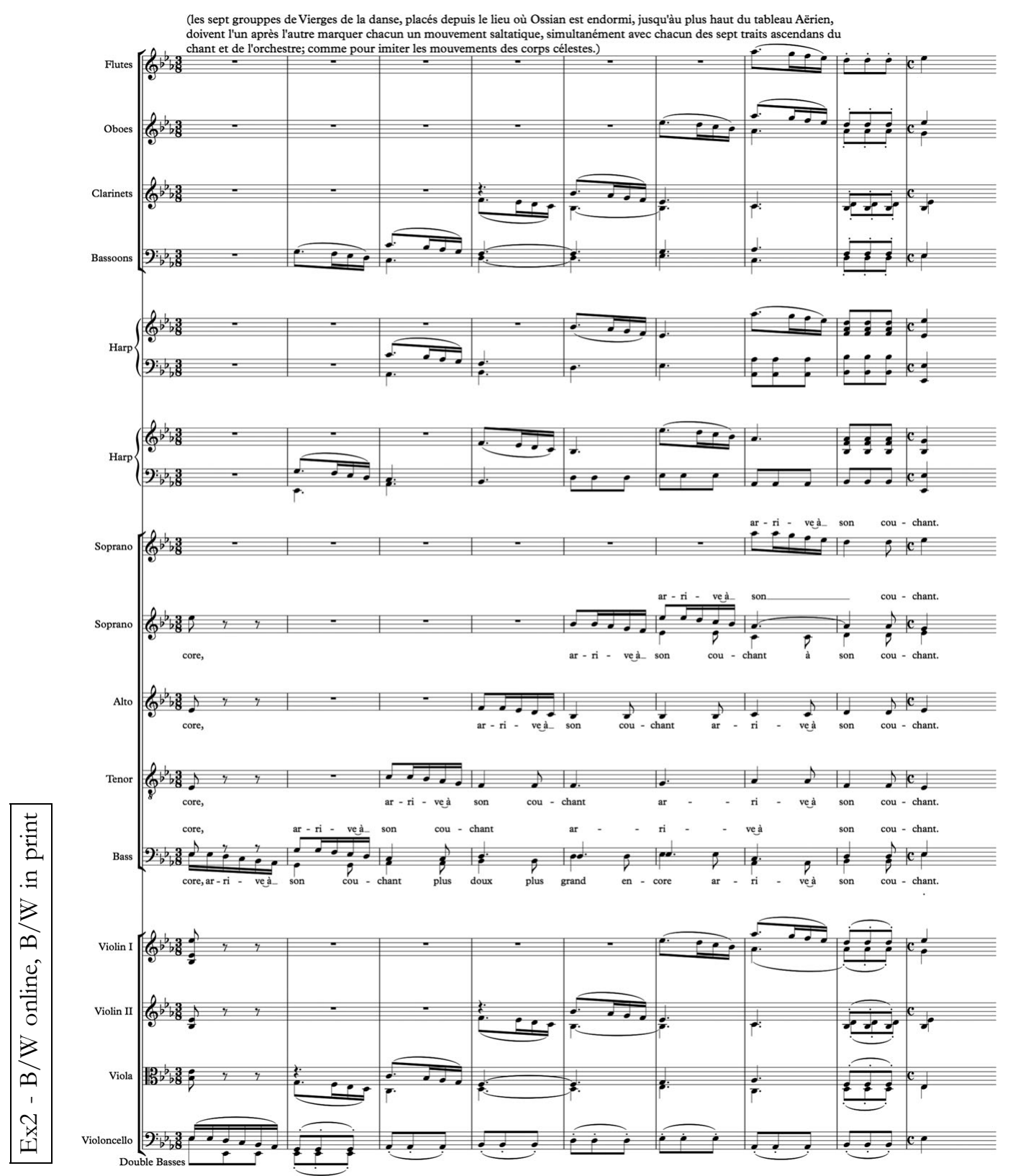

Ex. 2: The scene indication above the score specifies that 'the seven groups of virgins from among the dancers that are positioned between the place where Ossian sleeps and the highest level of the aerial tableau have to make an acrobatic movement one after the other simultaneous with each of the ascending figures in the choir and the orchestra as if they are imitating the movements of the heavenly bodies'. This excerpt comes from the end of the dream, just before an abbreviated version of the opening chorus returns to close the scene. 
Allegro ma non troppo
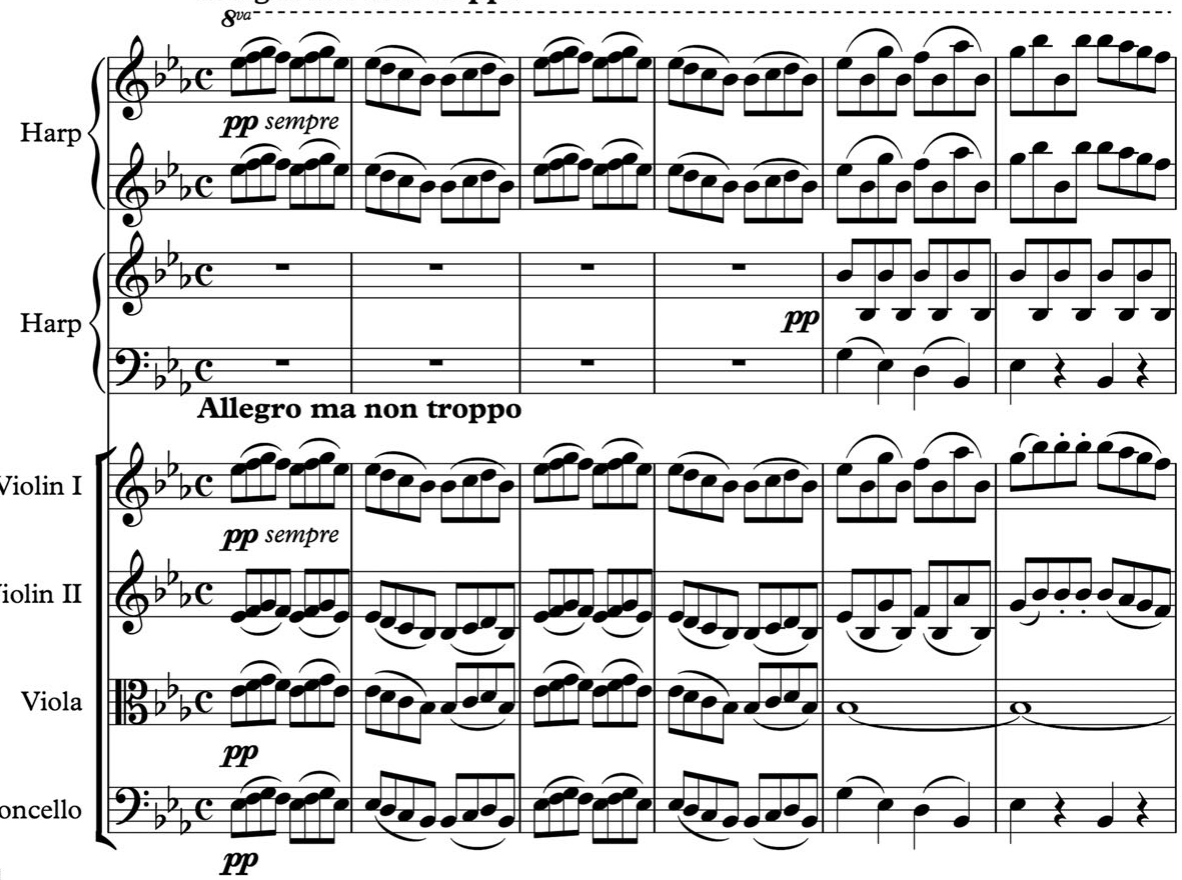

Ex. 3: This harp and string figuration marks the transition to and from the dream in Act IV 
of festivals organised after the Reign of Terror because such a linkage was thought to increase the festivals' potential for eliciting strong emotional responses. ${ }^{113}$

Reviews did not openly comment on Ossian's political message nor on any similarity with Revolutionary festivals. Even acknowledgements that the premiere's timing was related to the recent proclamation of the First Empire were scarce. ${ }^{114}$ The absence of such information is to be expected; such remarks may either have been too obvious or they may have made the article susceptible to censorship. Yet the press reception did nurture the suggestion of a link between Macpherson's bards and France's Gaulish ancestors. The critic of the Courrier des spectacles was one of many to precede his review with a brief tribute to Ossianic culture and its military valour. ${ }^{115}$ He made a direct connection with French genealogies when claiming that Charlemagne - considered the first 'French King' - had attempted to preserve the slowly disappearing bardic culture by putting its heroic epics in writing. And he repeated the contention attributed to Madame de Staël that Ossian should be considered the 'Homer of the North'. 116

At least one critic suggested that the staging of the dream had meant that audiences could 'identify' with the Ossianic world, and he attributed this effect to the overwhelming impact of the union of the arts:

Because of the enchantment the spectator experiences, he believes he lives in the real Elysée, or rather, the illusion submits his mind to the mythology of the Caledonians. He believes himself admitted among the heroes and immortal bards, and participates with them in the delights that intoxicate them ... [The choreographer Pierre Gardel] makes

113 James Livesey, Making Democracy in the French Revolution (Cambridge, 2001), 213-15.

114 This situation was only alluded to in two journals: the Gazette nationale ou Le moniteur universel of 23 messidor an XII (12 July 1804) lauded Ossian as a success suitably marking the Opéra's renaming as the Académie impériale de musique. The other was L'ambigu of July 1804, a satirical journal that bulged with anti-governmental statements and took the opportunity to criticise the assumed influence of the emperor on the Opéra's repertoire: 'On annonçait depuis longtemps l'opéra des bardes; cet opéra, dont nous avons donné plus haut l'extrait, a été sifflé d'un bout à l'autre, moins à cause de ses défauts, que par la raison que l'on supposait que ce sujet avait été mis au théâtre pour plaire à Napoléon, qui, comme on sait, est admirateur enthousiaste d'Ossian, des Bardes, des nuages, des ombres, des spectres et de tout le systême de la Phantasmagorie.' ('The premiere of the Bard was announced for a long time; this opera, of which we have given a review above, was booed from beginning to end, less for its flaws than because the subject was thought to have been put on stage to please Napoleon, who, as we know, is an enthusiastic admirer of Ossian, the bards, clouds, shadows, spectres and all kinds of phantasmagoria.') This account contradicts all the reports of Ossian's success in the French newspapers. Whereas it is possible that the reports of success were exaggerated - possibly for censorship reasons - the truthfulness of the account in L'ambigu is also in question, especially since the majority of its reviews (including the one of Ossian in this issue) were reprints of Geoffroy's articles in the Journal des débats and the Journal d'Empire. Thus, there is little evidence that the journal had someone regularly attend the Opéra to write specifically for them.

116 Courrier des spectacles. Madame de Staël had first made this contention in De la littérature considérée dans ses rapports avec les institutions sociales (1800). It was an oft-repeated comparison in turn-of-the-century Ossianism and reviews of Le Sueur's opera. Since Homeric epics had formed the basis of many an opera plot, such claims surely served to disprove any lingering questions about Ossian's origins as an opéra comique and thus its suitability for the Opéra. 
us experience how much power the arts have over our souls; how much their union fills all our senses with ravishing sensations; how much they bring us close to the Divinity. ${ }^{117}$

The critics thus partook in the wider discourse that gave pride of place to France's Gaulish roots. By suggesting that the opera had created a palpable link between past and present, they contributed to the transformation of the nation's conception of its identity. ${ }^{118}$ This new genealogy would live on despite the dwindling belief in the authenticity of Macpherson's 'translation'. It was further propagated in the continuation of Celtomania and the veneration of Vercingetorix, the Gaulish chieftain famous for his brave attempts to halt Caesar's legions - a more historically accurate replacement for Ossian. ${ }^{119}$

1321

1322

1323

1324

1325

1326

1327

1328

1329

1330

1331

1332

1333

1334

\section{Nation-building and opera's union of the arts}

The analysis of Le Sueur's Ossian highlights that the Opéra's early nineteenth-century emphasis on the union of the arts was neither a mere artistic aspiration nor specifically tied to Napoleon's aesthetic preferences. It was connected to contemporary considerations about opera's role in processes of nation-building. This connection between aesthetics and politics was not exclusive to the staging of Ossian; it became an important topic in debates on theatrical illusion as suggested in the writings of Jacques-François-Louis Grobert.

Grobert worked his way up in Napoleon's army, becoming war commissioner and assistant inspector of journals. ${ }^{120} \mathrm{He}$ was also an inventor and highly interested in all kinds of theatrical events. ${ }^{121}$ In 1802, he wrote an essay entitled Des fêtes publiques chez. les modernes ('On Modern Public Festivals'), where he argued that festivals were useful tools to create communal excitement and cohesion among its diverse audiences. ${ }^{122}$ In order to do so, it was necessary to create an overpowering event in which all elements were designed specifically to celebrate a nation's victories and moral values - whether the architecture, costumes, decorations; the theatre and firework displays; or the balls, music performances and horse races. He put these principles into practice in a design for Napoleon's coronation festivities. ${ }^{123} \mathrm{He}$ also tried his hand at theatre itself: his $\mathrm{La}$

117 Journal de la littérature, des arts et de commerce, 5 thermidor an XII (24 July 1804).

118 Like most other reviewers, the critic of the Courrier was hesitant to designate Macpherson's poems forgeries, but without choosing sides he still acknowledged the debate about their authenticity.

119 Dawson, 'Fingal meets Vercingetorix, 224-6.

120 He was dismissed as commissioner of war in 1805 for unspecified misbehavior in Italy. See 'Extrait des minutes de la Secrétairerie d'État', 6 nivôse an XIV (27 December 1805).

121 In 1804, Grobert invented a device to measure the velocity of projectiles. Jacques-François-Louis Grobert, Machine pour mésurer la vitesse initiale des mobiles de différens calibres (Paris, an XII [1804]).

122 Jacques-François-Louis Grobert, Des fêtes publiques chę les modernes (Paris, an X [1802]).

123 No documentation survives attesting that Grobert's design was used for the actual events of that day, even though there are many similarities. These resemblances may be coincidental because several practices - such as aligning the street decorations, architectural structures and the free music and theatre performances with the theme of the event -were common in Revolutionary festivals too. Colonel Grobert, 'Programme d'une fête pour l'Inauguration de Napoléon Premier
1335

1336

1337

1338

1339

1340

1341

1342

1343

1344

1345

1346

1347

1348

1349

1350

1351

1352

1353

1354

1355

1356

1357

1358

1359

1360

1361

1362

1363

1364 
bataille des pyramides premiered at the Théâtre de la Porte Saint-Martin in 1803. This opéra-mélodrame sought to bring this famous episode of the Egyptian campaign (17989) back to life by combining text, music and spectacular sets and costumes. It was openly propagandistic and at least in part aimed at enticing young men to enlist. ${ }^{124}$

The publication, however, that most meticulously engaged with theatrical production was a treatise tellingly titled De l'exécution dramatique considérée dans ses rapports avec le matériel de la salle et de la scène ('On Theatrical Production Considered in Relation to the Material Conditions of the Auditorium and the Stage'). ${ }^{125}$ This work details how the conditions for a most engaging performance can be created. In line with longstanding concerns about verisimilitude, he favoured three-dimensional sets over perspective paintings, for the latter were realistic only from a few seats in the hall. ${ }^{126}$ A specific reference to Ossian is made when he discusses the problem of using accelerated perspective in the backdrops. He lauded Gardel's ordering of the performers according to height to retain the perspectival effect, but complained that it had not been matched by the costumes, whose colour should grow dimmer the farther the figures are placed from the spectator. ${ }^{127}$ This was not the only element in the treatise that suggests a connection to Ossian's dream scene. Grobert argued that rather than a changement à vue (an open set change with the curtain raised), which made the spectator shift from appreciating the drama to admiring the machinists' technical skills, it would be better to maintain the dramatic illusion by changing the sets behind cloud panels. ${ }^{128}$ He preferred cloud panels over a drawn curtain, because this image was more conducive to the illusion of being transported from one place to another. Grobert was interested not only in what happened on stage, but also, as announced in the title, in how the conditions in the auditorium would influence the operatic experience. Therefore, he proposed hiding the orchestra in the wings, darkening the auditorium and creating a new architectural layout that made the theatre's ceiling into an 'acoustic mirror' so that every word and sound would be heard equally well in every seat - a rather modern idea. ${ }^{129}$

Even though Grobert's treatise seems to limit itself to aesthetic issues, traces of his ideas on the political utility of festivals are discernible. For instance, he shows an interest in making theatre and opera accessible and enjoyable for larger and more diverse audiences: he championed an enlargement of the 'paradis' for spectators buying the cheapest tickets, and the new layout would also ensure all these spectators heard (if not always saw) the performance equally well. While the treatise does not overtly claim that improved operatic illusion would enhance theatre's didactic

Empéreur des Français'. F-Pan AF iv $^{\text {10 }}$ 1049. A detailed account of Napoleon's coronation is given in Patrick Rambaud and Pierre-Jean Chalençon, eds., Le sacre de Napoléon (Neuilly-sur-Seine, 2004).

According to Hillmer, conscription agents were waiting at the doors of theatres at the end of performances of this nature. Hillmer, Die Napoleonische Theaterpolitik, 371-2.

125 Jacques-François-Louis Grobert, De l'exécution dramatique considérée dans ses rapports avec le matériel de la salle et de la scène (Paris, 1809).

126 Grobert, De l'exécution dramatique, 125-30.

127 Grobert, De l'exécution dramatique, 97-9.

128 Grobert, De l'exécution dramatique, 200-1.

129 Grobert, De l'exécution dramatique, 161-6 and 265-8. 
function, the dedication reveals that political education through theatre was a likely motivation for his theories. Grobert dedicated De l'exécution dramatique to Jean-Jacques-Régis de Cambacérès, Napoleon's Arch-Chancellor, and asked him to champion his improvements. His rationale was that the state would benefit from the advancement of the arts, and thus should also take part in bringing it about. ${ }^{130}$

Some of Grobert's measures to improve theatrical illusion uncannily prefigure those of Wagner, in that their primary goal is to eliminate all elements that could divert the audience's attention from the onstage drama. While it is unlikely that Wagner knew of Grobert's work, the treatise did spark considerable conversation in the following years. It was reviewed in the press, government officials discussed the possibilities for building new theatres that implemented his proposals in 1809 and 1810, and the members of the Institute de France debated his treatise extensively as late as $1816 .^{131}$ The surviving paper trail provides no solid evidence that either Grobert's or Le Sueur's theories had a direct impact on later practices and theories about uniting the arts in opera and their concomitant interest in producing overwhelming, absorbing performances.

Nevertheless, the dream scene became a point of comparison and emulation for years to follow. Le Sueur himself, for instance, sought to surpass its opulence in the final apotheosis of his La mort d'Adam (1809), which in turn became the blueprint for the finale in Rodolphe Kreuzer's La mort d'Abel (1810). ${ }^{132}$ Reference to these apotheoses were made as late as 1827 , when parts of their sets were reused in the finale of Gioacchino Rossini's Moïse. ${ }^{133}$ And, in 1893 - long after Ossian's last performance on 8 October 1817 - French theatre historian Germain Bapst asserted in his Histoire du théâtre that 'its mise en scène had seemed marvellous to its contemporary audience; it denoted not only a great effort, but a noticeable step forward in the art of making theatre.' ${ }^{134}$

The fame of such spectacular scenes cemented much of the Opéra's international prestige in the nineteenth century, allowing it to attract international audiences and composers alike. They also elicited Wagner's famous diatribe against French opera in Oper und Drama, but scholars have increasingly recognised the importance of universel on 12 October 1812. In the official documents of the Bureau des sciences et des arts, several letters survive (dating to the years 1809-10) discussing a new theatre building based on the recommendation made by Grobert. F-Pan AF ${ }^{\mathrm{iv}}$ 1290. The treatise was discussed at length by the class of fine arts in the Institut de France on 28 December 1816. See Catherine Giraudon and Jean-Michel Leniaud, eds., Procès verbaux de l'académie des beaux-arts. Vol. 2: 1816-1820 (Paris, 2002), 115-17.

132 The finale of Louis-Luc Loiseau de Persuis's Jérusalem délivrée (1812) was also inspired by this apotheosis. See Annelies Andries, Modernizing Spectacle: The Opéra in Napoleon's Paris (PhD diss., Yale University, 2018), 262-88.

133 See letter from Raphaël du Plantys to Sosthène de la Rochfoucauld, 18 January 1827. Reprinted in Bruno Cagli and Sergio Ragni, eds., Gioacchino Rossini, lettere e documenti (Pesaro, 1992), 122-3.

134 Germain Bapst, Essai sur l'histoire du théâtre (Paris, 1893), 529-30. 
the Paris Opéra as a source for his aesthetic theories and practices. ${ }^{135}$ This article has provided ideological reasons for similarities scholars have noted between Wagner's works and early nineteenth-century French operas such as Ossian by framing the Opéra's early nineteenth-century emphasis on 'uniting all the arts' in the context of the search for a French national opera. Yet, perhaps more importantly, I hope to have shown that acknowledging the political messages in Ossian does not preclude recognising its aesthetic merit. In fact, political and aesthetic importance are inextricably intertwined: thanks to the political utility attached to Ossian's artistic conception and its content, the Opéra was provided with sufficient governmental funds to execute its aesthetic programme in a successful manner and the opera achieved fame as 'a noticeable step forward in the art of making theatre'.

While I have framed Ossian in turn-of-the-nineteenth-century processes of nationbuilding, some caution is warranted when labelling Ossian a national opera. The Opéra's international outlook was at least as important as its function as a national theatre: it sought to exhibit to international audiences French artistic prowess and identity in its productions. This double function is also reflected in the nationalist narratives of Napoleonic France: they straddled Enlightenment (and imperialist) aspirations to universalise the (French) ideal and search for specifically French roots. In other words, such narratives sought to create greater national cohesion as well as international acclaim.

This polarity between universalising tendencies and particularity is reflected in Le Sueur's operatic aesthetics. While he sought to recreate a specific 'historical' and French past in Ossian, his approach to reconstructing the bards' ancient music was based largely on philosophical inquiries into the universal origins of language and music. This approach contrasted with the ethnographic methods of studying the thirdcentury Ossianic bards inspired by Macpherson's publications. ${ }^{136}$ Le Sueur's emphasis on universalism is in line with contemporary ideological discourse, which had its roots in Enlightenment thought. Yet, it was now taken up by the Revolutionary and Napoleonic governments as justification for their wars, which purportedly aimed to roll out newly discovered universal forms of sovereignty across the oppressed nations. ${ }^{137}$ Thus, Napoleon could be lauded in the opening panegyric as the 'liberating hero of an oppressed earth'. Le Sueur's particular Enlightenment-inspired musical search for universalism sets his Ossian apart from later nineteenth-century national opera: the emergent fields of folkloric and ethnographic studies would more often provide materials for 'national' musical styles that focused on a nation's particularity and distinctiveness.

1453

1454

1455

1456

1457

1458

1459

1460

1461

1462

1463

1464

1465

1466

1467

1468

1469

1470

1471

1472

1473

1474

1475

1476

1477

1478

1479

1480

1481

1482

1483

1484

1485

1486

1487

1488

1489

1490

1491

1492

1493

1494

1495

1496

136 Howard Gaskill, ed., The Reception of Ossian in Europe (London, 2004), xxi.

137 On the reception of the notion of Napoleon's 'universal monarchy' see Dwyer, The Citizen Emperor, $345-50$. 